\title{
Silicon Nanoparticles More Efficiently Alleviate Arsenate Toxicity than Silicon in Maize Cultiver and Hybrid Differing in Arsenate Tolerance
}

\author{
Durgesh Kumar Tripathi ${ }^{1}$, Swati Singh ${ }^{2}$, Vijay Pratap Singh ${ }^{3 *}$, Sheo Mohan Prasad ${ }^{4 *}$, \\ Devendra Kumar Chauhan ${ }^{4 *}$ and Nawal Kishore Dubey ${ }^{1 *}$ \\ ${ }^{1}$ Centre of Advanced Study in Botany, Banaras Hindu University, Varanasi, India, ${ }^{2}$ Department of Botany, Government \\ Ramanuj Pratap Singhdev Post Graduate College, Sarguja University, Baikunthpur, India, ${ }^{3}$ Ranjan Plant Physiology and \\ Biochemistry Laboratory, Department of Botany, University of Allahabad, Allahabad, India, ${ }^{4}$ D.D. Pant Interdisciplinary \\ Research Laboratory, Department of Botany, University of Allahabad, Allahabad, India
}

OPEN ACCESS

Edited by:

Aziz Ullah,

Kohat University of Science and

Technology, Pakistan

Reviewed by:

Peter Rolf Richter,

Friedrich-Alexander University

Erlangen-Nürnberg, Germany

Hoda Ahmed,

King Faisal University, Saudi Arabia

*Correspondence:

Vijay Pratap Singh

vijaypratap.au@gmail.com

Sheo Mohan Prasad profsmprasad@gmail.com

Devendra Kumar Chauhan

dkchauhanau@yahoo.com

Nawal Kishore Dubey

nkdubeybhu@gmail.com

Specialty section: This article was submitted to

Environmental Toxicology,

a section of the journal

Frontiers in Environmental Science

Received: 17 October 2015 Accepted: 03 June 2016

Published: 07 July 2016

Citation:

Tripathi DK, Singh S, Singh VP,

Prasad SM, Chauhan DK and

Dubey NK (2016) Silicon

Nanoparticles More Efficiently Alleviate Arsenate Toxicity than Silicon in Maize

Cultiver and Hybrid Differing in Arsenate Tolerance.

Front. Environ. Sci. 4:46.

doi: 10.3389/fenvs.2016.00046
Alleviation of abiotic stress by silicon (Si) is well documented. But mitigation of abiotic stress by silicon nanoparticles (SiNPs) is not much known. Therefore, hydroponic experiments were conducted to investigate if SiNPs are more effective than $\mathrm{Si}$ in mitigation of arsenate ( $\mathrm{As}^{\mathrm{V}} ; 25$ and $50 \mu \mathrm{M}$ ) toxicity in maize cultivar and hybrid differing in $A s^{V}$ tolerance. Under $\mathrm{As}^{\mathrm{V}}$ stress, reduction in growth was accompanied by enhanced level of $A s$ and oxidative stress. As ${ }^{V}$ inhibited activities of antioxidant enzymes like ascorbate peroxidase, glutathione reductase, and dehydroascorbate reductase (except superoxide dismutase). The redox status of ascorbate and glutathione was disturbed by $\mathrm{As}^{\vee}$ as indicated by a steep decline in their reduced/oxidized ratios. However, addition of $\mathrm{Si}$ and SiNp ameliorates $\mathrm{As}^{\mathrm{V}}$ toxicity in maize. Si and SiNp both could reduce As ${ }^{V}$ toxicity in maize cultivar and hybrid, which could be related with decreased accumulation of As and oxidative stress, and enhanced components of the ascorbate-glutathione cycle (AsA-GSH cycle). But lowering in the accumulation of As and oxidative stress markers, and enhancement in components of the AsA-GSH cycle was prominent in SiNp fed seedlings under $A s^{\vee}$ stress. The results also showed that $\mathrm{SiNp}$ are more effective in reducing $\mathrm{As}^{\vee}$ toxicity than $\mathrm{Si}$, which is due to their greater availability to seedlings. Comparing responses of cultivar and hybrid, maize cultivar shows more resistance against $A s^{\vee}$ than hybrid.

Keywords: arsenate, maize, photosynthesis, silicon, SiNp

\section{INTRODUCTION}

In last two decades, millions of people are exposed to arsenic (As) poisoning due to drinking of As-contaminated water (Nordstrom, 2002; Patel et al., 2005; Zhao et al., 2009; Singh R. et al., 2015; Singh et al., 2015a). Arsenic is found in different oxidation states, with the most dominant forms being trivalent $\left(\mathrm{As}^{\mathrm{III}}\right)$ and penta-valent $\left(\mathrm{As}^{\mathrm{V}}\right)$, which are classified as potent carcinogens

Abbreviations: AsA, reduced ascorbate; APX, ascorbate peroxidase; DHA, dehydroascorbate; DHAR, dehydrateascorbate reductase; $\mathrm{F}_{\mathrm{v}} / \mathrm{F}_{\mathrm{m}}$, maximum photochemical efficiency of PS II; GR, glutathione reductase; GSH, reduced glutathione; GSSG, oxidized glutathione; $\mathrm{H}_{2} \mathrm{O}_{2}$, hydrogen peroxide; MDA, malondialdehyde; NPQ, non-photochemical quenching; $\mathrm{qP}$, photochemical quenching; ROS, reactive oxygen species; $\mathrm{Si}$, silicon; SiNp, silicon nanoparticle; SOD, superoxide dismutase; SOR, superoxide radical. 
(Zhao et al., 2009). The potential sources of As in soil and water include both natural (e.g., weathering reactions, biological activity, volcanic emissions, etc.) and anthropogenic (mining, use of pesticides and wood preservatives, fossil fuels combustion, etc.; Patel et al., 2005; Zhao et al., 2009). Continuous increment in its concentration in the environment is one of the major public health problems all over the world. High As concentrations have been reported in different countries including, India, Bangladesh, China, Vietnam, Nicaragua, Brazil, France, USA, and several other countries (Patel et al., 2005; McClintock et al., 2012; Singh R. et al., 2015). In India, large area of water bodies and agricultural lands is highly polluted with As, being its concentrations between $50-300 \mathrm{mg} \mathrm{L}^{-1}$ and $32-105 \mathrm{mg}$ $\mathrm{kg}^{-1}$, respectively (Patel et al., 2005; Singh et al., 2015a,b). The level of As in drinking water is also higher $(0.3-0.5 \mathrm{mg}$ $\left.\mathrm{L}^{-1}\right)$ than the prescribed limit $\left(0.05 \mathrm{mg} \mathrm{L}^{-1}\right.$; Singh et al., 2015b). Studies have demonstrated that As adversely influences growth, development and metabolic process of plants, and consequently yield (Li et al., 2006; Ding et al., 2009; Singh et al., 2015b).

The transportation of $\mathrm{As}^{\mathrm{V}}$ into the plant cell takes place through phosphate transporters and thus, affects homeostasis of main source of energy i.e., ATP, while As ${ }^{\mathrm{III}}$ transportation occurs through aquaporins (nodulin26-like intrinsic protein family), and obstructs plant nutrient uptake, metabolism, and renovation of oxidative DNA damage (Kertulis-Tartar et al., 2009). There are increasing evidences, which show that As accelerates production of reactive oxygen species (ROS) such as superoxide radical $\left(\mathrm{O}_{2}^{\bullet-}\right)$ hydrogen peroxide $\left(\mathrm{H}_{2} \mathrm{O}_{2}\right)$, and hydroxyl radicals $(\bullet \mathrm{OH})$, causing major damage to the plant cell. Several studies demonstrated that As influences photosynthetic pigments, membrane system of chloroplasts, chlorophyll fluorescence, and RUBISCO enzyme (Li et al., 2006; Ding et al., 2009; Singh et al., 2015a,b). Thus, As causes adverse effects on plants from molecular to whole plant level.

Silicon ( $\mathrm{Si}$ ) is recognized as second most abundant element on the earth's crust and also one of the most prominent mineral constituents of some plants (Epstein, 1999). In the soil, it comprises more than $25 \%$ of the earth's crust (Currie and Perry, 2007) and is available to plants in the form of monosilicic acid $\left[\mathrm{Si}(\mathrm{OH})_{4}\right]$. Since few decades, physiological role of $\mathrm{Si}$ in the regulation of abiotic and biotic stresses in plants has made huge interest among researchers (Savant et al., 1997; Currie and Perry, 2007). Several studies demonstrated that Si has numerous direct and indirect beneficial impacts on plant growth and development. For instance, it appreciably enhances resistance of plants to several toxic metals such as aluminum (Al), chromium $(\mathrm{Cr})$, cadmium $(\mathrm{Cd})$ iron $(\mathrm{Fe})$, manganese $(\mathrm{Mn})$, and zinc $(\mathrm{Zn})$ (Horiguchi and Morita, 1987; Shi et al., 2005; Singh et al., 2011; Tripathi et al., 2012, 2015). There may be various strategies by which exogenous application of $\mathrm{Si}$ affects heavy metal resistance in plant species. It has been reported that Si supply could decrease the uptake of Mn (Horiguchi and Morita, 1987). However, Kidd et al. (2001) showed that Si stimulates maize root exudation of phenolics, which can chelate rhizosphere $\mathrm{Al}$ and thus, reduces its absorption. The valuable function of $\mathrm{Si}$ in resisting metal stress is well recognized in plants. However, an involvement of
Si-nanoparticles $(\mathrm{SiNp})$ in the regulation of metal stress is not yet well-known.

In last decade, nanotechnology has emerged as a prominent tool for enhancing agricultural productivity. Nanotechnology includes processing, generating, manipulating and deploying nanomaterials (having one or more proportions in the order of $100 \mathrm{~nm}$ or less). It has been documented that nanomaterials show size dependent behavior, distinctive optical properties and high surface area, thus exhibit significant role in plant protection and nutrition (Liu et al., 2009; Nair et al., 2010). In agro-nanotechnological research, efforts are being made to identify remedies for various stresses including heavy metals. Despite the availability of ample literature on metal stress, a relationship between metal stress and nanoparticle interaction, and nanoparticle-mediated alleviation of metal stress are still not well-known.

In past few decades, silicon $(\mathrm{Si})$ has emerged as one of the beneficial elements that involved in the regulation of various abiotic stresses in plants. However, little is known about involvement of silicon nanoparticles ( $\mathrm{SiNp}$ ) in the regulation of metal toxicity in plants. Therefore, in the present study our aims were to: (1) investigate effect of $\mathrm{Si}$ and $\mathrm{SiNp}$ on maize cultivar and hybrid (2) confirm whether SiNp or Si are more effective in alleviating $\mathrm{As}^{\mathrm{V}}$ toxicity in maize cultivar and hybrid (3) investigate the comparative impact of $\mathrm{Si}$ and nano-Si on antioxidant response of maize cultivar and hybrid under $\mathrm{As}^{\mathrm{V}}$ stress and (4) elucidate possible mechanisms by which nano-Si alleviates $\mathrm{As}^{\mathrm{V}}$ toxicity in maize seedlings.

\section{MATERIALS AND METHODS Synthesis and Characterization of Silicon
Nano-Particles (SiNp)}

Silicon nano-particles (SiNp) were synthesized by sol-gel synthesis method using sodium silicate $\left(\mathrm{Na}_{2} \mathrm{SiO}_{3}\right)$ according to the method of Liu et al. (2009) with some modifications. Briefly, $\mathrm{Na}_{2} \mathrm{SiO}_{3}$ was dissolved firstly in $475 \mathrm{~mL}$ distilled water $(5 \mathrm{mM})$, and then the $\mathrm{pH}$ was adjusted to 3 with $1 \mathrm{mM} \mathrm{HCl}$. After this, solution was stirred on water bath at $75^{\circ} \mathrm{C}$ for $2 \mathrm{~h}$. The $\mathrm{pH}$ of the acidified $\mathrm{Na}_{2} \mathrm{SiO}_{3}$ was adjusted to 7.0 with $\mathrm{NH}_{4} \mathrm{OH}$ at $75^{\circ} \mathrm{C}$ and solution mixed thoroughly for about $1.5 \mathrm{~h}$ on water bath. The obtained Si sol was further dialyzed with dialysis bag to remove impurities such as $\mathrm{Na}^{+}, \mathrm{NH}_{4}^{+}$, etc. and then evaporated to form the Si gel. The Si gel was further calcinated in furnace to obtain the SiNp powder. All solutions were freshly prepared at room temperature. The characterization of SiNp was performed by using scanning electron microscope (SEM), energy-dispersive $\mathrm{X}$-ray spectroscopy (EDS), UV-Vis spectrophotometer, and X-ray diffraction (XRD) analysis.

$\mathrm{XRD}$ was performed on Rigaku D/max-2200 PC diffractometer operated at $40 \mathrm{kV} / 40 \mathrm{~mA}$, using $\mathrm{CuK} \alpha 1$ radiation with wavelength of $1.54 \AA$ in the wide angle region from 20 to $80^{\circ}$ on $2 \theta$ scale. SEM was performed on Jeol JXA 8100 EPMA at $15 \mathrm{Kv}$ and the UV-Vis spectrum was recorded by systronic double beam spectrophotometer. EDS was also performed for the detection of elemental analysis. 


\section{Plant Materials and Growth Conditions}

Seeds of maize cultivar (Zea mays L. cv. Nootan) and hybrid (Z. mays L. hyb. Shaktiman-4) were purchased from certified supplier of local market. Seeds were surface sterilized in $10 \%(\mathrm{v} / \mathrm{v})$ sodium hypochlorite solution for $5 \mathrm{~min}$ and then washed thoroughly and soaked for $2-4 \mathrm{~h}$ in distilled water. After sterilization and soaking, uniform sized seeds were sown in plastic trays containing sterilized sand. Thereafter, trays were kept in the dark for seed germination at $25 \pm 2^{\circ} \mathrm{C}$. When germination reached maximum, seedlings were grown in a growth chamber (CDR model GRW-300 DGe, Athens) under photosynthetically active radiation (PAR) of $350 \mu \mathrm{mol}$ photons $\mathrm{m}^{-2} \mathrm{~s}^{-1}$ and $86-90 \%$ relative humidity with $16: 8 \mathrm{~h}$ day-night regime at $26 \pm 1^{\circ} \mathrm{C}$ for 15 days. During seedlings' growth, seedlings were sprayed with water whenever required. Uniformed sized seedlings were used to analyze the impact of Si and SiNp on various physiological and biochemical parameters of maize cultivar and hybrid under $\mathrm{As}^{\mathrm{V}}$ stress.

\section{SiNp, Si, and $\mathrm{As}^{\mathrm{V}}$ Treatments}

Uniform sized seedlings gently up rooted from sand and their roots were washed in tap water. Thereafter, seedlings were acclimatized in half strength Hoagland's nutrient solution for $24 \mathrm{~h}$. After this, $\mathrm{As}^{\mathrm{V}}$, $\mathrm{Si}$, and $\mathrm{SiNp}$ treatments were given. Sodium arsenate $\left(\mathrm{Na}_{2} \mathrm{HAsO}_{4} \cdot 7 \mathrm{H}_{2} \mathrm{O}\right)$ was used as a source of $\mathrm{As}^{\mathrm{V}}$ while sodium silicate $\left(\mathrm{Na}_{2} \mathrm{SiO}_{3}\right)$ was used as a source of $\mathrm{Si}$ and its nanoparticles. The $\mathrm{As}^{\mathrm{V}}$ concentrations $(25$ and $50 \mu \mathrm{M})$ which have been used in the present study are environmentally relevant while selection of $\mathrm{Si}$ and $\mathrm{SiNp}$ dose $(10 \mu \mathrm{M})$ was based on screening experiments. The treatments include: control (no added $\mathrm{As}^{\mathrm{V}}, \mathrm{Si}$, and $\left.\mathrm{SiNp}\right), \mathrm{Si}(10 \mu \mathrm{M}), \operatorname{SiNp}(10 \mu \mathrm{M}), 25 \mu \mathrm{M}$ $\mathrm{As}^{\mathrm{V}}, 25 \mu \mathrm{M} \mathrm{As}{ }^{\mathrm{V}}+10 \mu \mathrm{M}$ Si, $25 \mu \mathrm{M} \mathrm{As}^{\mathrm{V}}+10 \mu \mathrm{M}$ SiNp, $50 \mu \mathrm{M}$ $\mathrm{As}^{\mathrm{V}}, 50 \mu \mathrm{M} \mathrm{As}{ }^{\mathrm{V}}+10 \mu \mathrm{M}$ Si, and $50 \mu \mathrm{M} \mathrm{As}^{\mathrm{V}}+10 \mu \mathrm{M}$ SiNp. In case of $\mathrm{As}^{\mathrm{V}}+\mathrm{Si}$ and $\mathrm{As}{ }^{\mathrm{V}}+\mathrm{SiNp}$ treatments, seedlings were pre-treated with $\mathrm{Si}$ and $\mathrm{SiNp}$ for $24 \mathrm{~h}$ and then they were given $\mathrm{As}^{\mathrm{V}}$ treatments. Just after $\mathrm{As}{ }^{\mathrm{V}}$ and $\mathrm{Si}$ and $\mathrm{SiNp}$ treatments, seedlings were further grown in a growth chamber for 7 days under $350 \mu \mathrm{mol}$ photons $\mathrm{m}^{-2} \mathrm{~s}^{-1}$ of PAR and $86-90 \%$ relative humidity with $16: 8 \mathrm{~h}$ day-night regime at $26 \pm 1^{\circ} \mathrm{C}$. During this growth period, medium of various treatments was changed twice and aerated daily to avoid root anoxia. After 7 days of $\mathrm{As}^{\mathrm{V}}$, $\mathrm{Si}$, and $\mathrm{SiNp}$ treatments, seedlings were harvested and various parameters were analyzed immediately.

\section{Estimation of Growth and Photosynthetic Pigments}

Growth was measured in terms of root and shoots length and plant fresh weight. Seedlings were selected randomly from control and treated samples, divided into root and shoot and then their fresh weight and length were determined.

For the estimation of photosynthetic pigments, $20 \mathrm{mg}$ fresh leaves from control and treated seedlings were crushed in $5 \mathrm{ml}$ of $80 \%$ acetone and pigments were extracted and centrifuged. The absorbance of pigment extract was read at 663, 646, and $470 \mathrm{~nm}$. The amount of chlorophyll $a$, chlorophyll $b$, and carotenoids was calculated following the method of Lichtenthaler (1987).

\section{Estimation of as Content}

For the determination of As content, dried root and shoot samples $(50 \mathrm{mg})$ from control and treated seedlings were digested in mixed acid $\left(\mathrm{HNO}_{3}: \mathrm{HClO}_{4} ; 85: 15\right.$, v/v) until transparent solution was obtained. The volume of digested sample was maintained up to $30 \mathrm{~mL}$ with double distilled water. The content of As in digested samples was estimated by atomic absorption spectrometer (iCE3000 Series, model-3500 AAS, Thermo scientific, UK), fitted with specific lamp of particular metal using appropriate drift blank.

\section{Chlorophyll a Fluorescence Measurements}

For the assessment of photosynthetic performance, chlorophyll $a$ fluorescence measurements were taken in the dark adapted (30 $\mathrm{min}$ ) leaves of control and treated seedlings using hand held leaf fluorometer (FluorPen FP 100, Photon System Instrument, Czech Republic). The following fluorescence parameters: variable/maximum fluorescence ratio $\left(\mathrm{F}_{\mathrm{v}} / \mathrm{F}_{\mathrm{m}}\right)$, photochemical quenching ( $\mathrm{qP}$ ) and non-photochemical quenching (NPQ) were measured. Measurements were taken in second leaf of six different plants of each treatment (Strasser et al., 2000).

\section{Estimation of Superoxide Radical and Hydrogen Peroxide}

Superoxide radicals (SOR; $\mathrm{O}_{2}^{\bullet-}$ ) in control and treated seedlings were determined following the method of Elstner and Heupel (1976). This assay is based on formation of $\mathrm{NO}_{2}^{-}$from hydroxylamine in the presence of $\mathrm{O}_{2}^{\bullet-}$. Fresh leaves $(50 \mathrm{mg}$ ) were crushed in $65 \mathrm{mM}$ potassium phosphate buffer $(\mathrm{pH} 7.8)$ and centrifuged at $10,000 \mathrm{~g}$ for $10 \mathrm{~min}$ at $4^{\circ} \mathrm{C}$. The reaction mixture consisted of $65 \mathrm{mM}$ potassium phosphate buffer ( $\mathrm{pH} 7.8$ ), $10 \mathrm{mM}$ hydroxylamine hydrochloride and leaf extract and then incubated for $20 \mathrm{~min}$ at $25^{\circ} \mathrm{C}$. After this, $17 \mathrm{mM}$ sulfanilamide and $7 \mathrm{mM}$ naphthylethylene diamine dihydrochloride were mixed to the incubated reaction mixture. After $15 \mathrm{~min}$ of reaction, diethyl ether was mixed to the same reaction mixture gently and centrifuged at $2000 \mathrm{~g}$ for $5 \mathrm{~min}$. The absorbance of the colored aqueous phase was recorded at $530 \mathrm{~nm}$. A standard curve was prepared with $\mathrm{NaNO}_{2}$ and used to calculate the production of $\mathrm{O}_{2}^{\bullet-}$. The production of $\mathrm{NO}_{2}^{-}$is equivalent to generation of $\mathrm{O}_{2}^{\bullet-}$.

For the estimation of $\mathrm{H}_{2} \mathrm{O}_{2}$, fresh leaf samples (50 mg) from control and treated seedlings were crushed in $0.1 \%(\mathrm{w} / \mathrm{v})$ trichloroacetic acid (Velikova et al., 2000). The reaction mixture $(2 \mathrm{ml})$ contained tissue extract $(0.5 \mathrm{ml}), 10 \mathrm{mM}$ potassium phosphate buffer ( $\mathrm{pH} 7.0$ ), and $1 \mathrm{M} \mathrm{KI}$ solution. Absorbance of reaction mixture was recorded at $390 \mathrm{~nm}$ to read increase in turbidity. Hydrogen peroxide concentration was calculated by using a standard curve prepared with $\mathrm{H}_{2} \mathrm{O}_{2}$.

\section{Estimation of Lipid Peroxidation}

Lipid peroxidation as malondialdehyde (MDA) content was estimated according to the method of Heath and Packer (1968). Fresh leaves $(50 \mathrm{mg}$ ) from control and treated seedlings were crushed in 5\% (w/v) TCA and centrifuged at 10,000 g for $10 \mathrm{~min}$ at $4{ }^{\circ} \mathrm{C}$. Reaction mixture contained thiobarbituric acid (0.5\%)TCA (20\%) solution and tissue extract was boiled for $20 \mathrm{~min}$ in 
water bath. After cooling, the absorbance of reaction mixture (TBA-MDA) was recorded at 532 and $600 \mathrm{~nm}$. The values of nonspecific absorption recorded at $600 \mathrm{~nm}$ were subtracted from the values recorded at $532 \mathrm{~nm}$. The content of MDA was determined by using an extinction coefficient of $155 \mathrm{mM}^{-1} \mathrm{~cm}^{-1}$.

\section{Estimation of SOD, APX, GR, and DHAR Activities}

Superoxide dismutase (SOD; EC 1.15.1.1) activity was measured according to the method of Giannopolitis and Reis (1977). Fresh leaves $(50 \mathrm{mg}$ ) from control and treated seedlings were homogenized in EDTA-phosphate buffer $(50 \mathrm{mM}$; pH 7.8) and centrifuged at $15,000 \mathrm{~g}$ for $20 \mathrm{~min}$ at $4^{\circ} \mathrm{C}$ and supernatant was used as enzyme extract. Reaction mixture $(3 \mathrm{ml})$ contained $50 \mathrm{mM}$ potassium phosphate buffer $(\mathrm{pH} 7.8), 1.3 \mu \mathrm{M}$ riboflavin, $0.1 \mathrm{mM}$ EDTA, $13 \mathrm{mM}$ methionine, $63 \mu \mathrm{M}$ nitroblue tetrazolium (NBT), $0.05 \mathrm{M}$ sodium carbonate ( $\mathrm{pH} 10.2$ ), and enzyme extract $(0.1 \mathrm{ml})$. The reaction mixtures were illuminated for $20 \mathrm{~min}$ under white light intensity of $100 \mu \mathrm{mol}$ photons $\mathrm{m}^{-2} \mathrm{~s}^{-1}$. The photoreduction of NBT (formation of purple formazone) was recorded spectrophotometrically at $560 \mathrm{~nm}$ and compared with blank samples having no enzyme extract. One unit (U) of SOD activity is defined as the amount of enzyme required to cause $50 \%$ inhibition in reduction of NBT.

Ascorbate peroxidase (APX; EC 1.11.1.11) activity was determined according to the method of Nakano and Asada (1981). Fresh leaves $(50 \mathrm{mg}$ ) from control and treated seedlings were homogenized in $50 \mathrm{mM}$ potassium phosphate buffer $(\mathrm{pH}$ 7.0) containing $1 \mathrm{mM}$ EDTA, centrifuged at $15,000 \mathrm{~g}$ for $20 \mathrm{~min}$ at $4^{\circ} \mathrm{C}$ and supernatant was used as enzyme. Reaction mixture contained $50 \mathrm{mM}$ potassium phosphate buffer $(\mathrm{pH}$ 7.0) containing $1 \mathrm{mM}$ EDTA, $0.5 \mathrm{mM}$ ascorbate, $0.1 \mathrm{mM} \mathrm{H}_{2} \mathrm{O}_{2}$, and enzyme extract. The decrease in absorbance due to $\mathrm{H}_{2} \mathrm{O}_{2}$ decomposition was measured at $290 \mathrm{~nm}$. The enzyme activity was calculated by using an extinction coefficient of $2.8 \mathrm{mM}^{-1} \mathrm{~cm}^{-1}$. One unit (U) of enzyme activity is defined as $1 \mathrm{nmol}$ ascorbate oxidized $\min ^{-1}$.

Glutathione reductase (GR; EC 1.6.4.2) activity was assayed according to the method of Schaedle and Bassham (1977). The decrease in absorbance due to NADPH oxidation was read at $340 \mathrm{~nm}$, and GR activity was calculated using an extinction coefficient of $6.2 \mathrm{mM}^{-1} \mathrm{~cm}^{-1}$. One unit (U) of enzyme activity is defined as $1 \mathrm{nmol}$ NADPH oxidized $\mathrm{min}^{-1}$.

Dehydroascorbate reductase (DHAR; EC 1.8.5.1) activity was assayed by the method of Nakano and Asada (1981). An increase in absorbance due reduced ascorbate formation was read at $265 \mathrm{~nm}$, and DHAR activity was calculated using an extinction coefficient of $7.0 \mathrm{mM}^{-1} \mathrm{~cm}^{-1}$. One unit (U) of enzyme activity is defined as $1 \mathrm{nmol}$ DHA reduced $\mathrm{min}^{-1}$.

\section{Determination of Ascorbate and Glutathione}

Total ascorbate (AsA+DHA), reduced ascorbate (AsA), and dehydroascorbate (DHA) were determined by the method of Gossett et al. (1994). This assay is based on the reduction of $\mathrm{Fe}^{3+}$ to $\mathrm{Fe}^{2+}$ with ascorbic acid in acidic solution followed by formation of red chelate between $\mathrm{Fe}^{2+}$ and 2,2-bipyridyl. Ascorbate content was calculated using a standard curve prepared with $\mathrm{L}_{\text {-ascorbic acid. }}$

Total (GSH+GSSG), reduced (GSH) and oxidized glutathione (GSSG) contents were estimated by the enzyme recycling method of Brehe and Burch (1976). This method is based on sequential oxidation of GSH by 5, 5-dithiobis-2-nitrobenzoic acid (DTNB) and reduction of GSSG in the presence of NADPH and glutathione reductase (GR; Type III from bakers' yeast; Sigma Chemical Company). The amount of glutathione was determined by using a standard curve prepared with GSH.

\section{Statistical Analysis}

Results were statistically analyzed by analysis of variance (ANOVA). Duncan's multiple range test was applied for mean separation for significant differences among treatments at $P<$ 0.05 significance level. The results presented are the means \pm standard error of six replicates $(n=6)$.

\section{RESULTS}

\section{Characterization of SiNp}

The morphology of synthesized SiNp was investigated by SEM, which shows almost spherical nanoparticles with size ranges from 150 to $200 \mathrm{~nm}$ (Figure 1A). The Figure 1B demonstrated the size distributions of SiNps with an average diameter of $170 \pm$ $10 \mathrm{~nm}$, calculated by measuring more than 100 particles in SEM images. The XRD pattern of the synthesized SiNp is shown in Figure 1C, which appears as broad band's with expression at $2^{\prime \prime}=$ $22.8^{\circ}$ representing that synthesized material is amorphous and composed of $\mathrm{SiO}_{2}$ (Sooksaen et al., 2008). Elemental analysis of the sample using energy-dispersive energy-dispersive X-ray spectroscopy (EDS) is shown in Figure 1D. The analysis clearly indicates presence of silicon, carbon and oxygen in SiNPs. The UV-Vis spectroscopic analysis of synthesized SiNp was carried out in the range of $320-800 \mathrm{~nm}$ and shown in Figure 1E. The UV-Vis spectrum of SiNp clearly shows the absorption peak around $\sim 445 \mathrm{~nm}$ (Wilder et al., 1998).

\section{Impact of Si and SiNp on Growth and As Accumulation under $\mathbf{A s}^{\mathrm{v}}$ Stress}

Growth measured in terms of fresh weight was reduced significantly $(P<0.05)$ following $A s \mathrm{~V}$ treatments in both maize cultivar and hybrid (Figure 2). Treatment with 25 and $50 \mu \mathrm{M}$ of As ${ }^{\mathrm{V}}$ reduced growth by 14 and $29 \%$ in maize cultivar while 19 and $34 \%$ in hybrid, respectively compared to the control. On the other hand, Si addition along with $\mathrm{As}^{\mathrm{V}}$ treatments $(25$ and $50 \mu \mathrm{M})$ alleviated $\mathrm{As}^{\mathrm{V}}$-induced reduction in growth of maize cultivar and hybrid as percentage decline was only 7 and $19 \%$ and 8 and $22 \%$, respectively. However, the addition of $\mathrm{Si}$ alone enhanced fresh mass of maize cultivar and hybrid by 6 and 7\%, respectively over the value of control. Besides this, addition of SiNp along with 25 and $50 \mu \mathrm{M}$ of $\mathrm{As}^{\mathrm{V}}$ also significantly $(P<0.05)$ alleviated $\mathrm{As}^{\mathrm{V}}$-induced reduction in growth of maize cultivar and hybrid as reductions were only 4 and $12 \%$ and 5 and $16 \%$, respectively. Thus, data indicate that $\mathrm{SiNp}$ were more effective in reducing $(P<0.05) \mathrm{As}^{\mathrm{V}}$ toxicity than Si. Furthermore, the addition of 


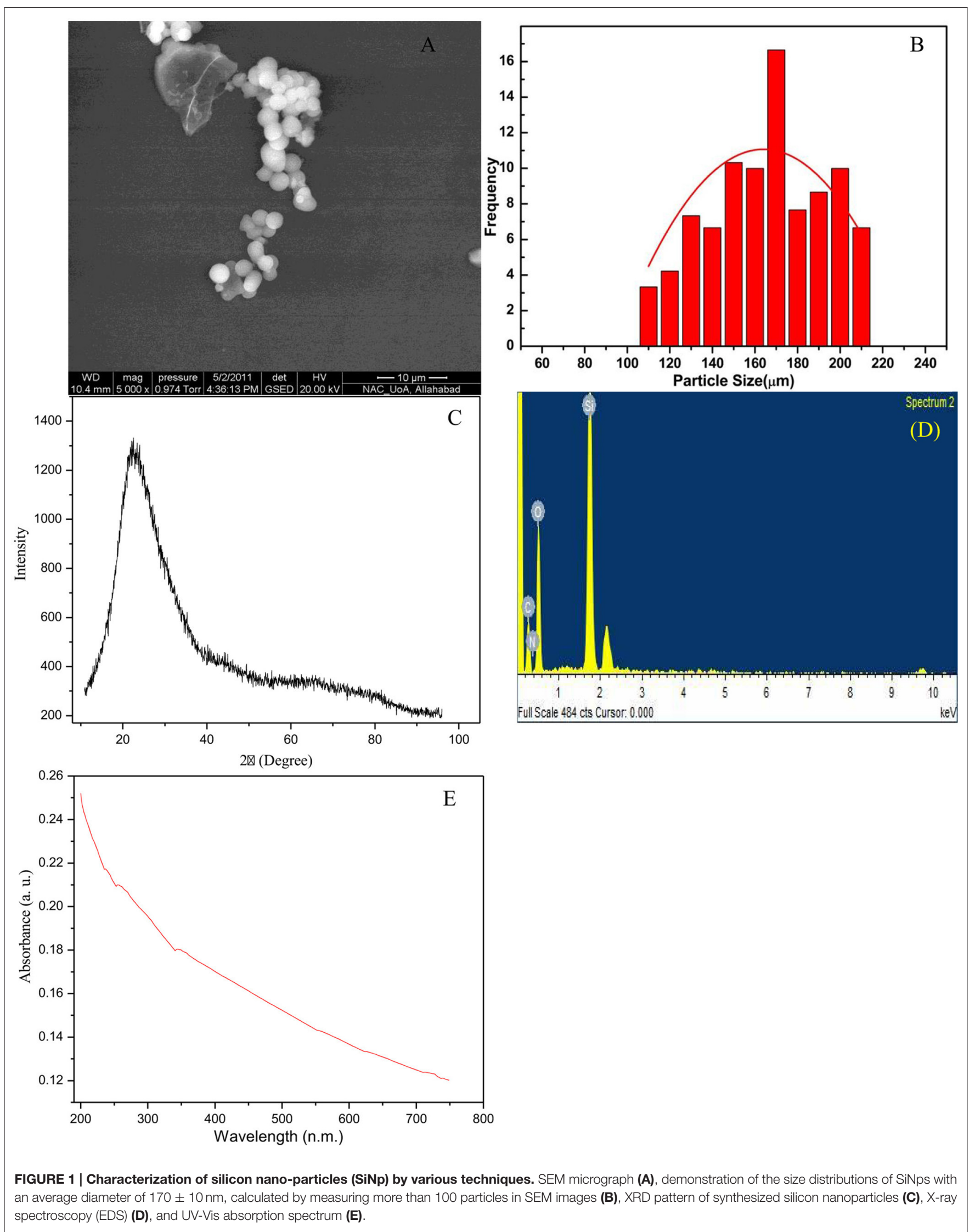




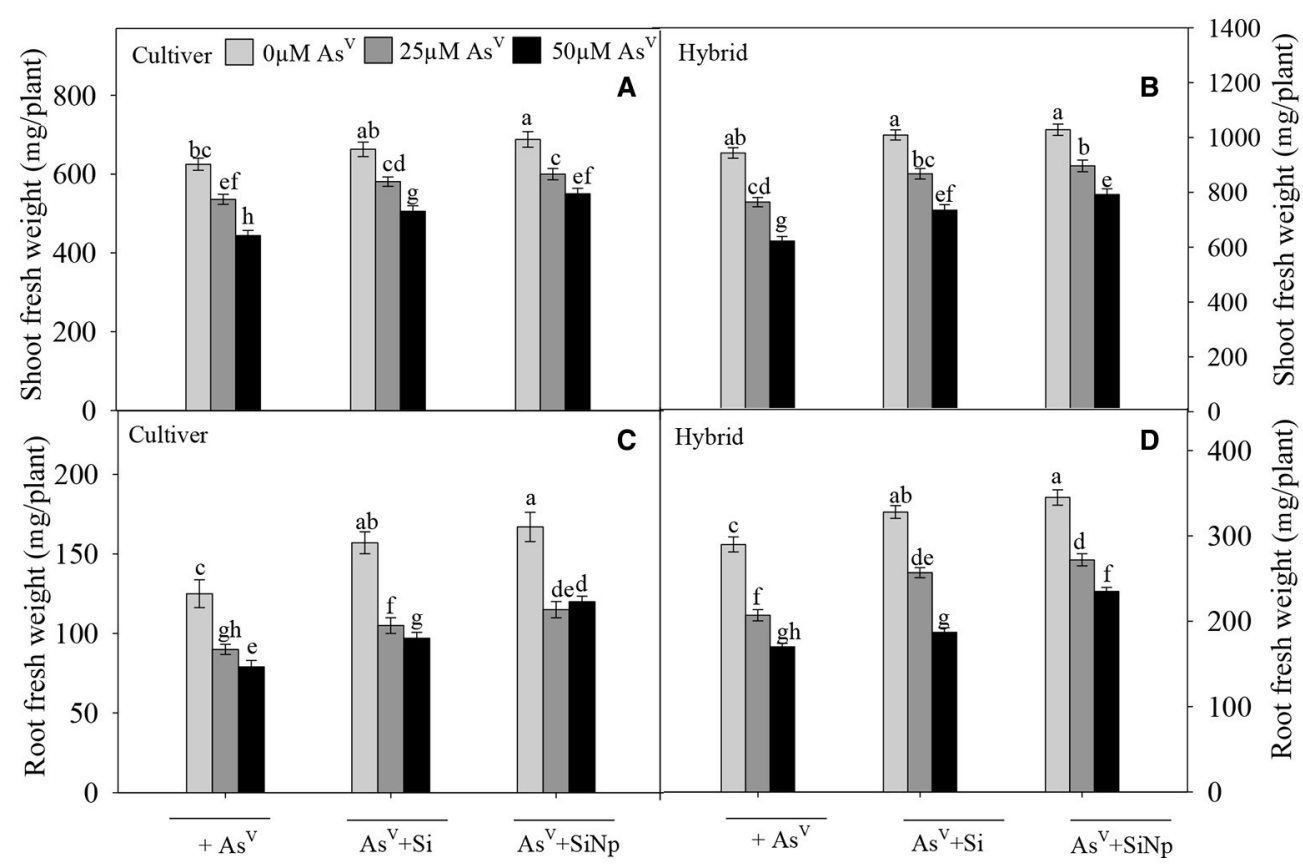

FIGURE 2 | Effects of Si and silicon nanoparticles (SiNp) on growth (fresh weight of roots and shoots), of maize cultivar (A,C) and hybrid exposed (B,D) to $\mathbf{A} \mathbf{V}$ stress. Data are means \pm standard error of three independent experiments with two replicates in each experiment $(n=6)$. Bars followed by different letter(s) show significant difference at $P<0.05$ significance level according to the Duncan's multiple range test.

SiNp alone significantly increased fresh mass of maize cultivar and hybrid by 10 and $9 \%$, respectively over the respective value of control (Figure 2).

Similar to the $\mathrm{As}^{\mathrm{V}}$-induced reduction in growth, the accumulation of As was significantly $(P<0.05)$ higher in $\mathrm{As}^{\mathrm{V}}$ stressed maize cultivar and hybrid (Figure 3). Maize cultivar and hybrid seedlings grown under 25 and $50 \mu \mathrm{M}$ of $\mathrm{As}^{\mathrm{V}}$ treatments accumulated about 124 and $272 \mu \mathrm{g}$ As $\mathrm{g}^{-1}$ dry weight and 156 and $312 \mu \mathrm{g} \mathrm{As} \mathrm{g}^{-1}$ dry weight, respectively. However, with the addition of $\mathrm{Si}\left(25 \mu \mathrm{M} \mathrm{As} \mathrm{V}^{2}+\mathrm{Si}\right.$ and $\left.50 \mu \mathrm{M} \mathrm{As}{ }^{\mathrm{V}}+\mathrm{Si}\right)$ metal accumulation significantly reduced and it was only 110 and $226 \mu \mathrm{g} \mathrm{As} \mathrm{g}^{-1}$ dry weight and 136 and $246 \mu \mathrm{g} \mathrm{As} \mathrm{g}^{-1}$ dry weight in maize cultivar and hybrid seedlings, respectively (Figure 3). Similarly, the addition of SiNp with 25 and $50 \mu \mathrm{M}$ of $\mathrm{As}^{\mathrm{V}}$ also significantly $(P<0.05)$ reduced the accumulation of As in maize cultivar and hybrid as accumulation was only 104 and $212 \mu \mathrm{g} \mathrm{As} \mathrm{g}^{-1}$ dry weight and 126 and $234 \mu \mathrm{g} \mathrm{As} \mathrm{g}^{-1}$ dry weight, respectively.

\section{Impact of Si and SiNp on Photosynthetic Pigments Under As ${ }^{\mathrm{v}}$ Stress}

Data pertaining to the photosynthetic pigments i.e., total chlorophyll, carotenoids, and protein are presented in Table 1. The results reveal that $\mathrm{As}^{\mathrm{V}}(25$ and $50 \mu \mathrm{M})$ treatments significantly $(P<0.05)$ declined chlorophyll contents of maize cultivar by 8 and $16 \%$ while in hybrid it was declined by 11 and $19 \%$, respectively. Similar to the results of chlorophyll content, carotenoids, and total protein were also significantly decreased in maize cultivar and hybrid. Under 25 and $50 \mu \mathrm{M}$ of $\mathrm{As}^{\mathrm{V}}$ treatments, carotenoids and protein were decreased by 6 and
$13 \%$ and 16 and $24 \%$ in cultivar and by 9 and $16 \%$ and 18 and $27 \%$, respectively in hybrid (Table 1 ). On the other hand, the addition of Si and SiNp in nutrient medium alleviated $(P<0.05)$ $\mathrm{As}^{\mathrm{V}}$-induced decline in total chlorophyll, carotenoids and total protein in comparison to the $\mathrm{As}^{\mathrm{V}}$ treatments alone (Table 1).

\section{Impact of Si and SiNp on Photosynthetic Performance under $\mathrm{As}^{\mathrm{v}}$ Stress}

The results pertaining to changes in chlorophyll $a$ fluorescence parameters such as $\mathrm{F}_{\mathrm{v}} / \mathrm{F}_{\mathrm{m}}, \mathrm{qP}$, and NPQ are shown in Figures $4 \mathrm{~A}-\mathrm{F}$. The results reveal that $\mathrm{As}^{\mathrm{V}}(25$ and $50 \mu \mathrm{M})$ exposure decreased $\mathrm{F}_{\mathrm{V}} / \mathrm{F}_{\mathrm{m}}$ and $\mathrm{qP}$ by 11 and $19 \%$ and 14 and $21 \%$ in maize cultivar while by 14 and $22 \%$ and 16 and $24 \%$ in hybrid, respectively as compared to the control (Figures 4A-D). In contrast to this, treatment of plants with $\mathrm{As}^{\mathrm{V}}$ at 25 and $50 \mu \mathrm{M}$ increased NPQ by 18 and 25\% in maize cultivar and by 21 and $28 \%$, respectively in hybrid (Figures $4 \mathrm{E}, \mathbf{F}$ ). On the other hand, Si and SiNP treatments alone did not bring significant $(P<0.05)$ changes in chlorophyll $a$ fluorescence parameters. Furthermore, the addition of $\mathrm{Si}$ and $\mathrm{SiNp}$ with $\mathrm{As}^{\mathrm{V}}$ significantly $(P<0.05)$ ameliorated $\mathrm{As}^{\mathrm{V}}$-induced negative impacts on $\mathrm{F}_{\mathrm{v}} / \mathrm{F}_{\mathrm{m}}, \mathrm{qP}$, and NPQ in comparison to the As ${ }^{\mathrm{V}}$ treatments alone (Figure 4).

\section{Impact of Si and SiNp on Reactive Oxygen Species and Lipid Peroxidation under As ${ }^{v}$ Stress}

It has been reported in earlier studies that $\mathrm{As}^{\mathrm{V}}$ stress was associated with the production of ROS, which ultimately cause 


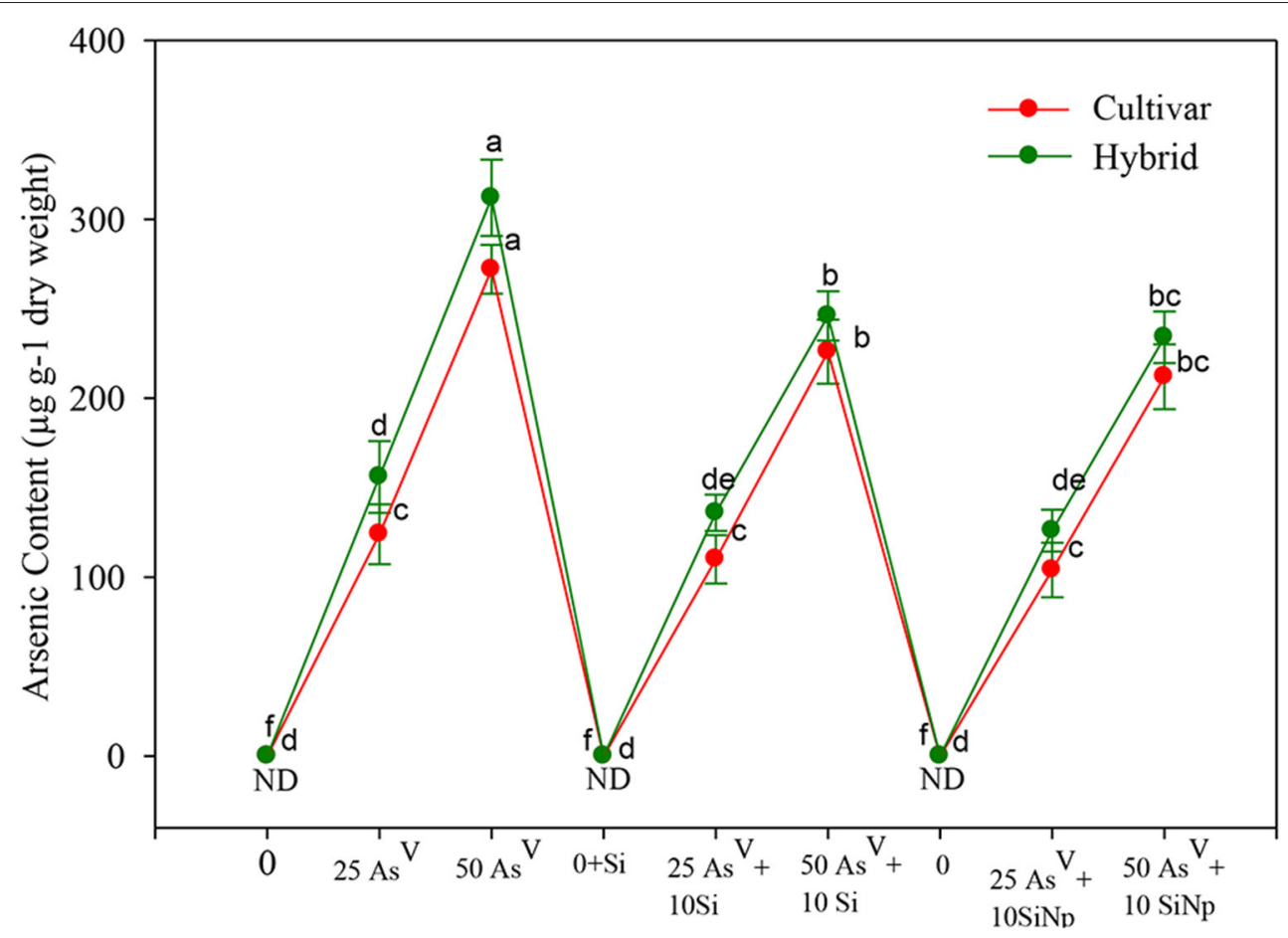

FIGURE 3 | Effects of Si and silicon nanoparticles (SiNp) on the accumulation of As in maize cultivar and hybrid exposed to As ${ }^{\mathbf{V}}$ stress. Data are means \pm standard error of three independent experiments with two replicates in each experiment $(n=6)$. Bars followed by different letter(s) show significant difference at $P<0.05$ significance level according to the Duncan's multiple range test.

damage to macromolecules. Therefore, in order to investigate oxidative stress in both maize cultivar and hybrid, we examined levels of SOR and $\mathrm{H}_{2} \mathrm{O}_{2}$ in plants whose growth was suppressed substantially by $\mathrm{As}^{\mathrm{V}}(25$ and $50 \mu \mathrm{M})$. The results show that 25 and $50 \mu \mathrm{M}$ of $\mathrm{As}^{\mathrm{V}}$ enhanced SOR and $\mathrm{H}_{2} \mathrm{O}_{2}$ content by 18 and $27 \%$ and 24 and $32 \%$ in maize cultivar and by 23 and $32 \%$ and 28 and 37\%, respectively in hybrid (Figures 5A-D). Contrary to $\mathrm{As}^{\mathrm{V}}, \mathrm{Si}$, and $\mathrm{SiNp}$ treatments alone did not significantly $(P<0.05)$ change SOR and $\mathrm{H}_{2} \mathrm{O}_{2}$ contents in maize cultivar and hybrid (Figures 5A-D). Further, when $\mathrm{Si}$ and $\mathrm{SiNp}$ was added jointly with $\mathrm{As}^{\mathrm{V}}$, they significantly $(P<0.05)$ reduced $\mathrm{As}^{\mathrm{V}}$-mediated enhancement in SOR and $\mathrm{H}_{2} \mathrm{O}_{2}$. Under $25 \mu \mathrm{M}$ $\mathrm{As}^{\mathrm{V}}+\mathrm{Si}, 50 \mu \mathrm{M} A s^{\mathrm{V}}+\mathrm{Si}, 25 \mu \mathrm{M} \mathrm{As}^{\mathrm{V}}+\mathrm{SiNp}$, and $50 \mu \mathrm{M} \mathrm{As}^{\mathrm{V}}$ + SiNp combinations, SOR declined up to 11 and 17\%, 6 and $10 \%$ in cultivar and 15 and $20 \%$ and 7 and $11 \%$ in hybrid while $\mathrm{H}_{2} \mathrm{O}_{2}$ decreased up to 14 and $21 \%$ and 6 and $11 \%$ in cultivar and 18 and $24 \%$ and 9 and 14\%, respectively in hybrid (Figures 5A-D).

Lipid peroxidation is a marker to measure the effect of abiotic stresses such as $\mathrm{As}^{\mathrm{V}}$ stress on lipids. Accordingly, 25 and $50 \mu \mathrm{M}$ of $\mathrm{As}^{\mathrm{V}}$ also enhanced lipid peroxidation (MDA content) by 28 and $34 \%$ in maize cultivar and by 32 and $38 \%$, respectively in hybrid (Figures $\mathbf{5 E}, \mathbf{F}$ ). On the other hand, the addition of $\mathrm{Si}$ and SiNp alone did not influence the production of MDA in maize cultivar and hybrid. Besides this, they significantly $(P<0.05)$ lowered $\mathrm{As}^{\mathrm{V}}$-induced lipid peroxidation in maize cultivar and hybrid as MDA content declined up to 18 and $10 \%$ in cultivar and 21 and $15 \%$ in hybrid under $25 \mu \mathrm{M} \mathrm{As}{ }^{\mathrm{V}}+\mathrm{Si}$ and $25 \mu \mathrm{M} \mathrm{As}{ }^{\mathrm{V}}+\mathrm{SiNp}$ combinations and 24 and $14 \%$ in cultivar and 26 and $18 \%$ in hybrid, respectively, under $50 \mu \mathrm{M} \mathrm{As}{ }^{\mathrm{V}}+\mathrm{Si}$ and $50 \mu \mathrm{M} \mathrm{As}^{\mathrm{V}}+\mathrm{SiNp}$ combination (Figures 5E,F).

\section{Impact of Si and SiNp on the Activities of Enzymatic Antioxidants Under As ${ }^{v}$ Stress}

In order to investigate the role of $\mathrm{Si}$ and $\mathrm{SiNp}$ in the regulation of antioxidant enzymes and the relationship between ROS and the cellular defense system, the activities of SOD, APX, GR, and DHAR were examined in $\mathrm{As}^{\mathrm{V}}$-stressed maize cultivar and hybrid with and without $\mathrm{Si}$ and SiNp supplementation. The results related to the activities of enzymatic antioxidants are shown in Table 2. The results show that $\mathrm{As}^{\mathrm{V}}$ treatments $(25$ and $50 \mu \mathrm{M})$ significantly $(P<0.05)$ increased SOD activity in maize cultivar and hybrid. In contrast to SOD activity, 25 and $50 \mu \mathrm{M}$ of $\mathrm{As}^{\mathrm{V}}$ significantly $(P<0.05)$ inhibited the activities of APX $(24$ and $31 \%$ and 31 and $38 \%$ ), GR (28 and $34 \%$ and 32 and $39 \%$ ), and DHAR (34 and 39\% and 38 and 44\%) in maize cultivar and hybrid, respectively as compared to the value of control (Table 2). In contrast to this, $\mathrm{Si}$ and SiNp alone significantly $(P<0.05)$ increased the activity of all enzymes studied in maize cultivar and hybrid. Moreover, the addition of $\mathrm{Si}$ and $\mathrm{SiNp}$ with $\mathrm{As}^{\mathrm{V}}$ significantly alleviated $\mathrm{As}^{\mathrm{V}}$-mediated inhibitions in APX, GR, and DHAR (Table 2). 
TABLE 1 | Effects of Si and silicon nanoparticles (SiNp) on total chlorophyll (total Chl), carotenoids (Car) and protein content of maize cultivar and hybrid exposed to $\mathrm{As}^{\mathrm{V}}$ stress.

\begin{tabular}{|c|c|c|c|c|c|c|}
\hline & \multicolumn{2}{|c|}{ Total Chl ( $\mu \mathbf{g ~ g}^{-1}$ fresh weight) } & \multicolumn{2}{|c|}{ Car ( $\mu \mathbf{g ~ g}^{-1}$ fresh weight) } & \multicolumn{2}{|c|}{ Protein (mg g ${ }^{-1}$ fresh weight) } \\
\hline & Cultiver & Hybrid & Cultiver & Hybrid & Cultiver & Hybrid \\
\hline \multicolumn{7}{|c|}{$\operatorname{As}^{V}(\mu \mathrm{M})$} \\
\hline 0 & $1370 \pm 23.8 \mathrm{ab}$ & $1480 \pm 24.1 c$ & $446 \pm 7.1 \mathrm{ab}$ & $481 \pm 7.3 b$ & $12.4 \pm 0.20 c$ & $12.7 \pm 0.20 \mathrm{ab}$ \\
\hline 25 & $1260 \pm 19.3 d$ & $1317 \pm 23.2 \mathrm{ef}$ & $419 \pm 5.7 \mathrm{bc}$ & $438 \pm 5.1 d$ & $10.4 \pm 0.10 f g$ & $10.4 \pm 0.13 \mathrm{~g}$ \\
\hline 50 & $1151 \pm 17.9 \mathrm{e}$ & $1199 \pm 20.3 g$ & $288 \pm 4.6 e$ & $404 \pm 4.8 e$ & $9.4 \pm 0.10 h$ & $9.3 \pm 0.14 h$ \\
\hline \multicolumn{7}{|c|}{$A s^{V}(\mu M)+S i$} \\
\hline 0 & $1439 \pm 26.9 a$ & $1569 \pm 25.7 a b$ & $464 \pm 9.1 a$ & $505 \pm 7.3 a$ & $12.8 \pm 0.12 \mathrm{ab}$ & $13.2 \pm 0.16 a$ \\
\hline 25 & $1329 \pm 22.1 \mathrm{bc}$ & $1406 \pm 26.1 \mathrm{~cd}$ & $432 \pm 8.0 a b$ & $457 \pm 5.7 \mathrm{bc}$ & $11.4 \pm 0.18 \mathrm{e}$ & $11.4 \pm 0.13 \mathrm{de}$ \\
\hline 50 & $1247 \pm 20.2 d$ & $1332 \pm 18.9 e$ & $410 \pm 6.1 \mathrm{~cd}$ & $338 \pm 4.2 f$ & $10.5 \pm 0.18 f$ & $10.7 \pm 0.15 f$ \\
\hline \multicolumn{7}{|c|}{$\operatorname{As}^{\mathbf{V}}(\mu \mathrm{M})+\operatorname{SiNp}$} \\
\hline 0 & $1466 \pm 27.3 a$ & $1613 \pm 28.7 a$ & $473 \pm 5.3 a$ & $515 \pm 7.1 \mathrm{a}$ & $13.0 \pm 0.17 a b$ & $13.3 \pm 0.22 a$ \\
\hline 25 & $1356 \pm 18.7 a b$ & $1450 \pm 23.3 c$ & $437 \pm 4.3 a b$ & $471 \pm 5.6 b$ & $12.0 \pm 0.11 d$ & $12.1 \pm 0.14 c$ \\
\hline 50 & $1315 \pm 12.5 b c$ & $1406 \pm 21.6 c d$ & $424 \pm 5.3 \mathrm{bc}$ & $462 \pm 4.8 \mathrm{bc}$ & $13.6 \pm 0.13 a$ & $11.7 \pm 0.12 \mathrm{~cd}$ \\
\hline
\end{tabular}

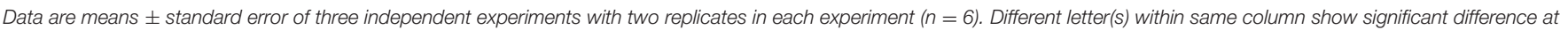
$P<0.05$ significance level according to the Duncan's multiple range test.

TABLE 2 | Effects of Si and silicon nanoparticles (SiNp) on the activities of superoxide dismutase (SOD), ascorbate peroxidase (APX), glutathione

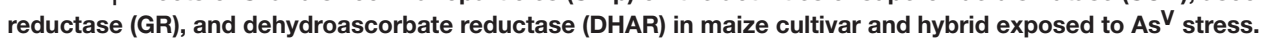

\begin{tabular}{|c|c|c|c|c|c|c|c|c|}
\hline \multirow[t]{2}{*}{ Treatments } & \multicolumn{2}{|c|}{ SOD Units $\mathrm{mg}^{-1}$ protein } & \multicolumn{2}{|c|}{ APX Units $\mathrm{mg}^{-1}$ protein } & \multicolumn{2}{|c|}{ GR Units $\mathrm{mg}^{-1}$ protein } & \multicolumn{2}{|c|}{ DHAR Units $\mathrm{mg}^{-1}$ protein } \\
\hline & Cultiver & Hybrid & Cultiver & Hybrid & Cultiver & Hybrid & Cultiver & Hybrid \\
\hline \multicolumn{9}{|l|}{$A s^{V}(\mu M)$} \\
\hline 0 & $44.5 \pm 1.8 \mathrm{~g}$ & $32.7 \pm 1.7 \mathrm{gh}$ & $24,342 \pm 197.6 c$ & $26,572 \pm 166 c$ & $86.7 \pm 4.3 c$ & $67.8 \pm 1.4 c$ & $887.6 \pm 10.4 c$ & $643.7 \pm 10.6 \mathrm{ab}$ \\
\hline 25 & $58.7 \pm 1.3 b$ & $46.4 \pm 1.1 b$ & $18,500 \pm 184 \mathrm{gh}$ & $18,334 \pm 191 \mathrm{~h}$ & $62.4 \pm 2.5 \mathrm{gh}$ & $46.1 \pm 1.3 \mathrm{gh}$ & $585.8 \pm 11.6 h$ & $399.1 \pm 8.9 \mathrm{fg}$ \\
\hline 50 & $83.3 \pm 2.2 a$ & $51.0 \pm 1.6 a$ & $16,796 \pm 175 i$ & $16,474 \pm 183 i$ & $57.2 \pm 1.6 i$ & $41.3 \pm 1.2 \mathrm{i}$ & $541.4 \pm 9.3 i$ & $360.5 \pm 5.4 h$ \\
\hline \multicolumn{9}{|c|}{$A s^{V}(\mu M)+S i$} \\
\hline 0 & $46.5 \pm 1.3 \mathrm{ef}$ & $33.7 \pm 1.7 \mathrm{~g}$ & $26,046 \pm 247 \mathrm{ab}$ & $28,963 \pm 249 b$ & $91.9 \pm 2.6 a b$ & $73.2 \pm 1.3 \mathrm{ab}$ & $976.4 \pm 7.3 \mathrm{ab}$ & $682.3 \pm 9.5 a$ \\
\hline 25 & $54.3 \pm 1.6 \mathrm{~cd}$ & $43.2 \pm 1.5 \mathrm{~cd}$ & $20,447 \pm 239 f$ & $21,257 \pm 242 f$ & $69.4 \pm 1.7 f$ & $51.5 \pm 1.4 f$ & $692.3 \pm 12.5$ ef & $463.5 \pm 6.8 \mathrm{de}$ \\
\hline 50 & $58.7 \pm 1.4 \mathrm{bc}$ & $45.1 \pm 1.1 \mathrm{bc}$ & $18,743 \pm 233 g$ & $19,132 \pm 228 g$ & $63.3 \pm 1.3 \mathrm{~g}$ & $47.5 \pm 1.1 \mathrm{~g}$ & $630.2 \pm 9.7 \mathrm{~g}$ & $418.4 \pm 5.7 f$ \\
\hline \multicolumn{9}{|c|}{$\operatorname{As}^{V}(\mu M)+\operatorname{SiNp}$} \\
\hline 0 & $45.4 \pm 1.9$ ef & $33.1 \pm 1.7 \mathrm{~g}$ & $27,019 \pm 191 a$ & $30,026 \pm 233 a$ & $94.5 \pm 2.4 a$ & $75.9 \pm 1.2 \mathrm{a}$ & $1011.9 \pm 14.8 a$ & $695.2 \pm 8.9 a$ \\
\hline 25 & $51.6 \pm 1.6 \mathrm{de}$ & $39.2 \pm 1.2 \mathrm{ef}$ & $22,394 \pm 198 d$ & $23,383 \pm 242 d$ & $77.2 \pm 3.2 d$ & $56.9 \pm 1.3 d$ & $763.3 \pm 9.9 d$ & $527.8 \pm 7.4 \mathrm{c}$ \\
\hline 50 & $53.4 \pm 1.9 \mathrm{cde}$ & $41.5 \pm 1.9 e$ & $21,421 \pm 189 \mathrm{e}$ & $22,055 \pm 237 \mathrm{e}$ & $72.8 \pm 2.8 \mathrm{de}$ & $54.2 \pm 1.6 \mathrm{de}$ & $718.9 \pm 8.7 e$ & $482.8 \pm 4.4 d$ \\
\hline
\end{tabular}

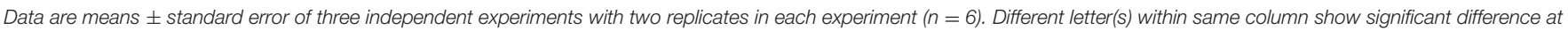
$P<0.05$ significance level according to the Duncan's multiple range test.

\section{Impact of Si and SiNp on Ascorbate and Glutathione Levels under $\mathbf{A s}^{\mathrm{v}}$ Stress}

The results related to amounts of ascorbate and glutathione and their redox status are shown in Tables 3, 4. Under $\mathrm{As}^{\mathrm{V}}$ $(25$ and $50 \mu \mathrm{M})$ treatments, though total ascorbate increased by 14 and $25 \%$ in cultivar and 13 and $21 \%$ in hybrid and total glutathione content enhanced by 17 and $29 \%$ in cultivar and 12 and $24 \%$, respectively in hybrid, however, their oxidized forms increased $(p<0.05)$ by 154 and $263 \%$ in cultivar and 168 and $199 \%$ in hybrid and 166 and $371 \%$ in cultivar and 175 and $350 \%$, respectively in hybrid (Tables 3,4 ). This results into a steep decline in reduced ascorbate/dehydroascorbate and reduced glutathione/oxidized glutathione ratios as they were only 6.8 and 4.2 in cultivar and 4.6 and 3.8 in hybrid and 5.4 and 3.4 in cultivar and 4.6 and 2.8 in hybrid, respectively following $\mathrm{As}^{\mathrm{V}}(25$ and $50 \mu \mathrm{M})$ exposure (Tables 3, 4). On the other hand, Si and SiNp alone enhanced levels of reduced ascorbate and glutathione as well as their reduced/oxidized ratios in maize cultivar and hybrid (Tables 3, 4). Furthermore, application of Si and SiNp together with $\mathrm{As}^{\mathrm{V}}(25$ and $50 \mu \mathrm{M})$ attenuated $\mathrm{As}^{\mathrm{V}}$-induced diminish in levels of reduced ascorbate and glutathione as well as their reduced/oxidized ratios in both maize cultivar and hybrid seedlings (Tables 3, 4). 


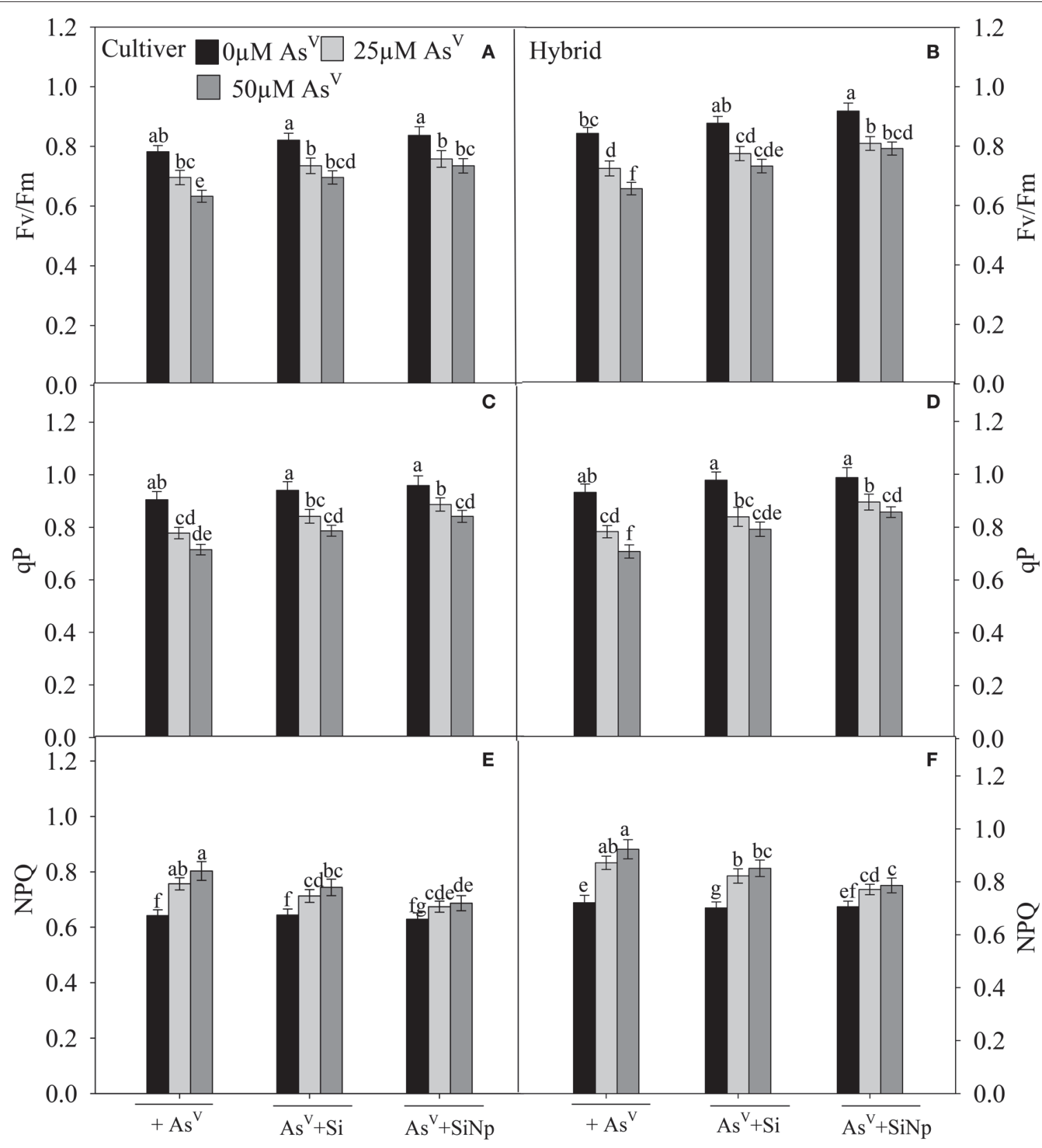

FIGURE 4 | Effects of Si and silicon nanoparticles (SiNp) on maximum photochemical efficiency of PS II ( $\left.F_{v} / F_{m}\right)(A, B)$, photochemical quenching (qP) $(C, D)$ and non-photochemical quenching (NPQ) $(\mathbf{E}, \mathbf{F})$ in maize cultivar and hybrid exposed to $\mathbf{A} \mathbf{s}^{\mathbf{V}}$ stress. Data are means \pm standard error of three independent experiments with two replicates in each experiment $(n=6)$. Bars followed by different letter(s) show significant difference at $P<0.05$ significance level according to the Duncan's multiple range test.

\section{DISCUSSION}

Similar to previous studies, the results of the present study revealed that $\mathrm{As}^{\mathrm{V}}$ significantly $(P<0.05)$ reduced growth of maize cultivar and hybrid seedlings, which has occurred due to the enhancement in the accumulation of As in seedlings (Figures 2, 3). This kind of $\mathrm{As}^{\mathrm{V}}$ toxicity response is welldocumented (Li et al., 2006; Singh R. et al., 2015; Singh et al., 2015a,b). Additionally, the results revealed that $\mathrm{As} \mathrm{V}$ negatively affects pigments, total protein, photosynthesis, and the status of antioxidants (SOD, APX, GR, and DHAR, reduced ascorbate and glutathione), and significantly increased level of oxidative stress markers like SOR, $\mathrm{H}_{2} \mathrm{O}_{2}$, and damage to lipids (Figures 4, 5; Tables 1-4). To explain As ${ }^{\grave{V}}$-induced toxicity in plants, numerous hypotheses, and mechanisms have been proposed but in the present investigation $\mathrm{As}^{\mathrm{V}}$-mediated toxicity 


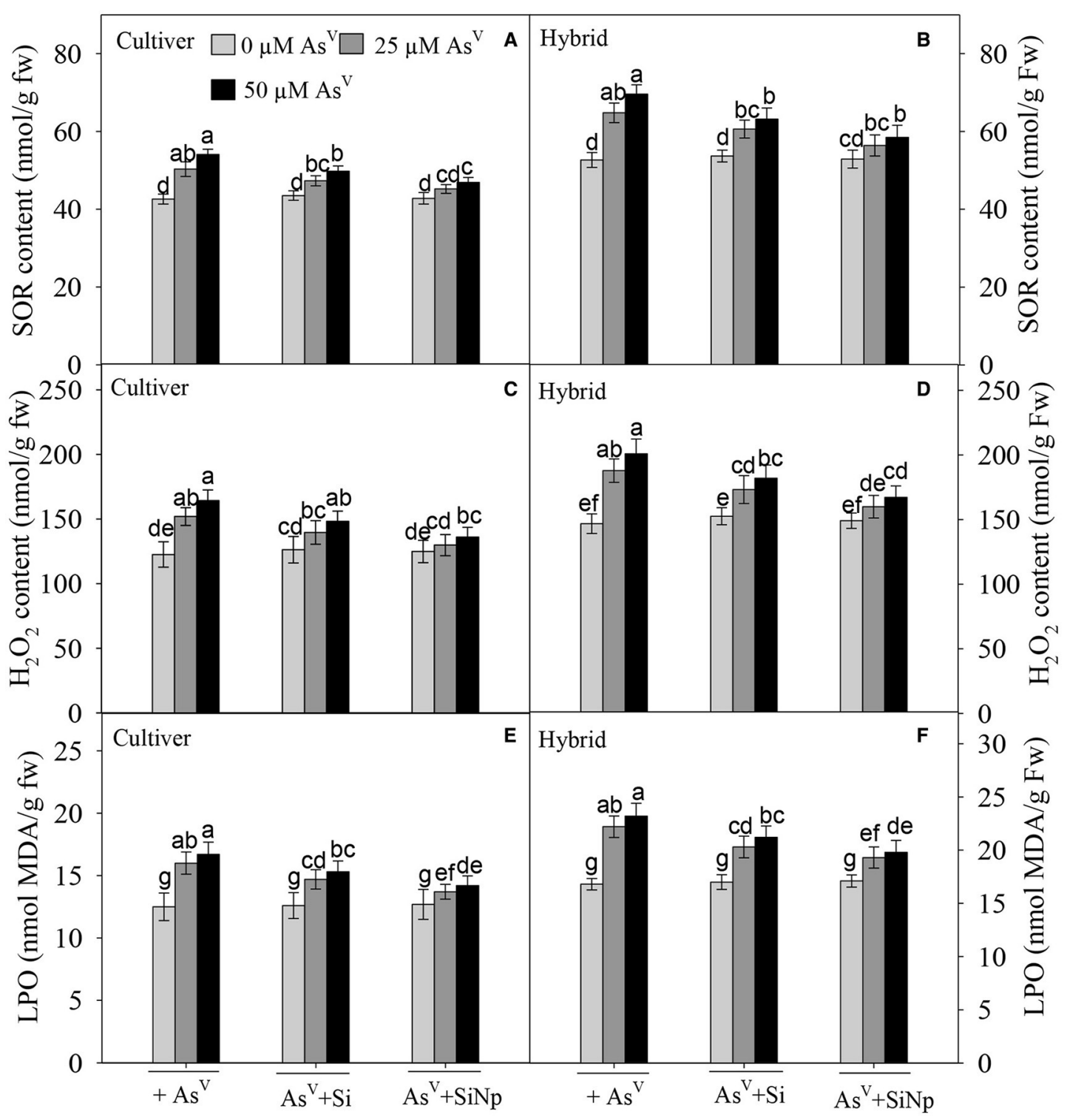

FIGURE 5 | Effects of $\mathrm{Si}$ and silicon nanoparticles (SiNp) on superoxide radicals (SOR) $(A, B)$, hydrogen peroxide $\left(\mathrm{H}_{2} \mathrm{O}_{2}\right)(\mathrm{C}, \mathrm{D})$ and lipid peroxidation (as MDA, malondialdehyde) (E,F) in maize cultivar and hybrid exposed to $\mathbf{A} \mathbf{v} \mathbf{v}$ stress. Data are means \pm standard error of three independent experiments with two replicates in each experiment $(n=6)$. Bars followed by different letter(s) show significant difference at $P<0.05$ significance level according to the Duncan's multiple range test.

to maize cultivar and hybrid seedlings may be associated with its harmful impacts on pigments, photosynthesis and macromolecules such as lipids due to higher accumulation of As.

On contrary, the addition of $\mathrm{Si}$ and SiNp significantly $(P<$ 0.05 ) reduced toxicity level of $\mathrm{As}^{\mathrm{V}}$ in maize cultivar and hybrid by ameliorating $\mathrm{As}^{\mathrm{V}}$-induced negative effects on growth, pigments, photosynthetic process and protein, which was accompanied by a decreased level of As accumulation (Figure 3; Table 1). Simediated alleviation of $\mathrm{As}^{\mathrm{V}}$ toxicity complies with mechanisms, which were reported in earlier studies (Horiguchi and Morita, 1987; Tripathi et al., 2015; Wang et al., 2015). Regarding SiNp-mediated alleviation of $\mathrm{As}^{\mathrm{V}}$ toxicity, somewhat similar mechanisms have been observed as reported for Si. For instance, lowering in the accumulation of As and oxidative damage and enhancement in antioxidant defense system (Figures 3, 5; Tables 2-4). In recent years, nanotechnology has been established as a powerful technology and shown a greater potential as an environment cleaner technology including alleviation of toxicities of various heavy metals (Dickinson and Scott, 2010). Further various studies also demonstrated metal nanoparticles mediated alleviation of metal toxicity in plants. (Dubchak et al., 2010; Wang et al., 2012). However, the role of nanoparticles and their mechanisms of action in plant growth and development is not yet well known. But their high surface 
TABLE 3 | Effects of Si and silicon nanoparticles (SiNp) on total ascorbate (AsA+DHA), reduced ascorbate (AsA), dehydroascorbate (DHA), and reduced ascorbate/dehydroascorbate ratio (AsA/DHA) in maize cultivar and hybrid exposed to As ${ }^{\mathrm{V}}$ stress.

\begin{tabular}{|c|c|c|c|c|c|c|c|c|}
\hline \multirow{3}{*}{$\begin{array}{l}\text { Treatments } \\
\text { As }_{(\mu M)}\end{array}$} & \multicolumn{8}{|c|}{ Total ascorbate (nmol $\mathrm{g}^{-1}$ fresh weight) } \\
\hline & \multicolumn{4}{|c|}{ Cultiver } & \multicolumn{4}{|c|}{ Hybrid } \\
\hline & AsA + DHA & AsA & DHA & AsA/DHA & AsA + DHA & AsA & DHA & AsA/DHA \\
\hline 0 & $644.5 \pm 12.9 \mathrm{~g}$ & $602.1 \pm 13.6 f$ & $42.4 \pm 1.4 f$ & $14.2 \pm 0.090 c$ & $567.7 \pm 17.6 \mathrm{~g}$ & $525.0 \pm 6.9 \mathrm{gh}$ & $42.7 \pm 2.7 \mathrm{gh}$ & $12.3 \pm 0.10 c$ \\
\hline 25 & $734.7 \pm 14.6 \mathrm{de}$ & $640.5 \pm 16.3 \mathrm{~cd}$ & $94.2 \pm 2.7 b$ & $6.8 \pm 0.70 h$ & $641.5 \pm 12.9 \mathrm{de}$ & $526.9 \pm 9.5 \mathrm{gh}$ & $114.6 \pm 3.7 b$ & $4.6 \pm 0.080 f$ \\
\hline 50 & $805.6 \pm 15.7 b c$ & $650.7 \pm 12.7 \mathrm{de}$ & $154.9 \pm 3.9 a$ & $4.2 \pm 0.60 i$ & $686.9 \pm 13.4 \mathrm{bc}$ & $543.8 \pm 8.3 g$ & $143.1 \pm 2.1 \mathrm{a}$ & $3.8 \pm 0.070 \mathrm{~g}$ \\
\hline \multicolumn{9}{|c|}{$\mathrm{As}^{\mathrm{V}}(\mu \mathrm{M})+\mathrm{Si}$} \\
\hline 0 & $696.1 \pm 11.8 f$ & $654.2 \pm 18.1 \mathrm{~cd}$ & $41.9 \pm 1.7 \mathrm{fg}$ & $15.6 \pm 0.10 a b$ & $601.8 \pm 11.3 f$ & $562.2 \pm 7.7 f$ & $39.6 \pm 1.3 \mathrm{hi}$ & $14.2 \pm 0.090 b$ \\
\hline 25 & $766.9 \pm 19.4 \mathrm{~cd}$ & $683.5 \pm 17.3 \mathrm{bc}$ & $83.4 \pm 2.2 \mathrm{~cd}$ & $8.2 \pm 0.060 f$ & $664.2 \pm 8.7 \mathrm{~cd}$ & $584.2 \pm 9.3 \mathrm{~cd}$ & $80.0 \pm 2.1 d$ & $7.3 \pm 0.080 e$ \\
\hline 50 & $818.5 \pm 20.1 \mathrm{ab}$ & $724.4 \pm 14.6 a b$ & $94.1 \pm 3.3 c$ & $7.7 \pm 0.080 f g$ & $681.2 \pm 11.2 \mathrm{bc}$ & $586.6 \pm 13.1 \mathrm{~cd}$ & $94.6 \pm 3.2 c$ & $6.2 \pm 0.067 \mathrm{~g}$ \\
\hline \multicolumn{9}{|c|}{$\left.\mathrm{As}^{\mathbf{V}} \mu \mathrm{M}\right)+\mathrm{SiNp}$} \\
\hline 0 & $741.2 \pm 15.4 \mathrm{~cd}$ & $697.8 \pm 15.7 \mathrm{bc}$ & $43.4 \pm 1.8 f$ & $16.1 \pm 0.10 a$ & $755.0 \pm 10.1 \mathrm{bc}$ & $707.2 \pm 6.9 a$ & $47.8 \pm 1.7 \mathrm{~g}$ & $14.8 \pm 0.091 a$ \\
\hline 25 & $799.2 \pm 14.6 \mathrm{bc}$ & $722.3 \pm 16.9 a b$ & $76.9 \pm 2.4 \mathrm{de}$ & $9.4 \pm 0.080 d$ & $686.9 \pm 7.6 b$ & $613.8 \pm 9.8 b c$ & $73.1 \pm 1.6 f$ & $8.4 \pm 0.051 d$ \\
\hline 50 & $850.7 \pm 13.9 a$ & $762.1 \pm 13.7 a$ & $88.6 \pm 2.7 \mathrm{~cd}$ & $8.6 \pm 0.070 \mathrm{e}$ & $720.9 \pm 9.8 a$ & $635.1 \pm 11 b$ & $85.8 \pm 2.7 \mathrm{de}$ & $7.4 \pm 0.042 \mathrm{e}$ \\
\hline
\end{tabular}

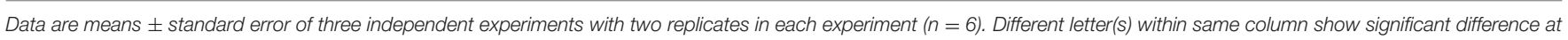
$P<0.05$ significance level according to the Duncan's multiple range test.

TABLE 4 | Effects of Si and silicon nanoparticles (SiNp) on total glutathione (GSH+GSSG), reduced glutathione (GSH), oxidized glutathione (GSSG) and reduced glutathione/oxidized glutathione ratio (GSH/GSSG) in maize cultivar and hybrid exposed to As ${ }^{\vee}$ stress.

\begin{tabular}{|c|c|c|c|c|c|c|c|c|}
\hline \multirow{3}{*}{$\begin{array}{l}\text { Treatments } \\
\qquad \mathbf{A s}^{\mathbf{V}}(\mu \mathrm{M})\end{array}$} & \multicolumn{8}{|c|}{ Total glutathione (nmol g ${ }^{-1}$ fresh weight) } \\
\hline & \multicolumn{4}{|c|}{ Cultiver } & \multicolumn{4}{|c|}{ Hybrid } \\
\hline & GSH + GSSG & GSH & GSSG & GSH/GSSG & GSH + GSSG & GSH & GSSG & GSH/GSSG \\
\hline 0 & $843.7 \pm 19.2 h$ & $785.5 \pm 8.2 \mathrm{e}$ & $58.2 \pm 6.1 \mathrm{gh}$ & $13.5 \pm 0.18 b c$ & $785.4 \pm 12.7 \mathrm{~g}$ & $728.5 \pm 14.8 d$ & $56.9 \pm 5.1 \mathrm{fg}$ & $12.8 \pm 0.10 b c$ \\
\hline 25 & $987.1 \pm 17.9$ ef & $832.1 \pm 7.7 e$ & $155.0 \pm 11.9 c$ & $5.4 \pm 0.10 \mathrm{~g}$ & $879.6 \pm 16.4$ ef & $722.5 \pm 17.5 d$ & $157.1 \pm 7.7 \mathrm{bc}$ & $4.6 \pm 0.11 \mathrm{gh}$ \\
\hline 50 & $1088.4 \pm 23.4 \mathrm{bc}$ & $841.0 \pm 9.3 f$ & $274.4 \pm 14.3 a$ & $3.4 \pm 0.11 i$ & $973.9 \pm 25.3 b c$ & $717.6 \pm 17.2 \mathrm{de}$ & $256.3 \pm 8.6 a$ & $2.8 \pm 0.9 i$ \\
\hline \multicolumn{9}{|c|}{$A s^{V}(\mu M)+S i$} \\
\hline 0 & $936.5 \pm 11.9 \mathrm{~g}$ & $873.6 \pm 8.9 \mathrm{~cd}$ & $62.9 \pm 7.7 \mathrm{~g}$ & $13.9 \pm 0.17 a b$ & $856.1 \pm 17.3 \mathrm{ef}$ & $796.2 \pm 16.2 \mathrm{bc}$ & $59.9 \pm 5.6 f$ & $13.3 \pm 0.18 a b$ \\
\hline 25 & $1046.2 \pm 18.4$ de & $910.3 \pm 9.1 \mathrm{~cd}$ & $135.9 \pm 16.7 \mathrm{de}$ & $6.7 \pm 0.13 e f$ & $926.8 \pm 18.7 \mathrm{~cd}$ & $796.3 \pm 17.8 \mathrm{bc}$ & $130.5 \pm 7.6 d$ & $6.1 \pm 0.14 \mathrm{e}$ \\
\hline 50 & $1113.7 \pm 24.3 a b$ & $934.1 \pm 7.9 \mathrm{bc}$ & $179.6 \pm 12.6 b$ & $5.2 \pm 0.10 \mathrm{gh}$ & $997.4 \pm 23.4 a b$ & $822.4 \pm 20.1 \mathrm{ab}$ & $175.0 \pm 9.2 b$ & $4.7 \pm 0.12 \mathrm{~g}$ \\
\hline \multicolumn{9}{|c|}{$A s^{V}(\mu M)+\operatorname{SiNp}$} \\
\hline 0 & $995.6 \pm 19.8 \mathrm{de}$ & $930.9 \pm 8.6 \mathrm{bc}$ & $64.7 \pm 7.9 \mathrm{~g}$ & $14.4 \pm 0.20 a$ & $895.3 \pm 16.5 \mathrm{~g}$ & $834.8 \pm 16.7 a b$ & $60.5 \pm 3.1 f$ & $13.8 \pm 10 a$ \\
\hline 25 & $1079.9 \pm 23.3 \mathrm{bc}$ & $957.2 \pm 9.7 b$ & $122.7 \pm 9.8 \mathrm{ef}$ & $7.8 \pm 0.11 d$ & $950.3 \pm 22.6 \mathrm{ef}$ & $828.5 \pm 18.3 a b$ & $121.8 \pm 8.1 \mathrm{de}$ & $6.8 \pm 0.11 d$ \\
\hline 50 & $1155.9 \pm 27.2 a$ & $1007.7 \pm 12.3 a$ & $148.2 \pm 11.2 d$ & $6.8 \pm 0.10 \mathrm{e}$ & $1028.9 \pm 29.3 \mathrm{bc}$ & $865.6 \pm 19.1 a$ & $163.3 \pm 7.8 \mathrm{bc}$ & $5.3 \pm 0.09 f$ \\
\hline
\end{tabular}

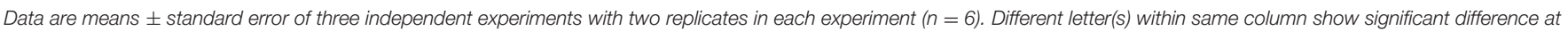
$P<0.05$ significance level according to the Duncan's multiple range test.

to volume ratio that increases their reactivity and possible biochemical activity of nanoparticles might play a role in their action (Adrees et al., 2015). Considering greater potential of $\mathrm{SiNp}$ in alleviating $\mathrm{AsV}$ stress than $\mathrm{Si}$, it is reported that $\mathrm{SiNp}$ have greater availability to seedlings than Si (unpublished data), thus exerting greater ameliorative effect in maize cultivar and hybrid.

At the present, several mechanisms are known by which $\mathrm{Si}$ alleviates abiotic stresses such as heavy metal toxicities, salinity, drought, chilling and freezing stresses. However, several other routes of $\mathrm{Si}$ action in mitigation of metal toxicity remain to be investigated. Some mechanisms, which are frequently discussed in the literature regarding Si-mediated alleviation of heavy metal stresses comprise: (1) stimulation of antioxidant systems, (2) complexation or co-precipitation of toxic metal ions with $\mathrm{Si}$, (3) immobilization of toxic metal ions in growth media, (4) uptake processes, (5) compartmentation of metal ions within plants, and (6) Si may modify the cation binding capacity of the cell wall (Kopittke et al., 2012). The results of the present study revealed that the addition of SiNp reduced As accumulation in maize cultivar and hybrid seedlings, which resulted into better photosynthetic performance, decreased levels of oxidative stress markers (ROS, $\mathrm{H}_{2} \mathrm{O}_{2}$, and $\mathrm{MDA}$ ) and improved antioxidant defense system (Figures 2-5; Tables 1-4). The reduction in As accumulation may be described on the basis of formation of barrier in root endodermis for $\mathrm{As}^{\mathrm{V}}$ as reported in other studies (Feng et al., 2009; Singh et al., 2013). Moreover, the addition of SiNp reduced membrane lipid 
peroxidation caused by excess metal and significantly improved cell wall breadth in root epidermis (data not shown), and thus declining As absorption and accumulation. It is reported that nano silica is easily absorbed by plants than inorganic silica (Suriyaprabha et al., 2012), and thus justifying greater protective impact of $\mathrm{SiNp}$ than $\mathrm{Si}$ under $\mathrm{As}^{\mathrm{V}}$ stress in maize seedlings.

Application of $\mathrm{Si}$ and SiNp lowered the level of oxidative stress. It is further proven by increased activity of superoxide dismutase (SOD). SOD comprises the first line of defense system against ROS which catalyzes dismutation of superoxide anion into $\mathrm{H}_{2} \mathrm{O}_{2}$ and $\mathrm{O}_{2}$ in chloroplast. Significant enhancement of SOD has been reported in an earlier study (Kuniak and Skodowska, 2001). In the present study, the activity of SOD in cultivar and hybrid maize treated with $\mathrm{As}^{\mathrm{V}}$ and $\mathrm{Si}$ and SiNp together showed enhanced activity, which suggested the important role of SOD in scavenging ROS. However, application of Si and SiNp decreased SOD activity in cultivar and hybrid maize (Table 2). These results imply that it might be due to lower accumulation of superoxide anion in cultivar and hybrid maize seedlings. It has been well documented that the ascorbate-glutathione (AsA-GSH cycle) cycle is the main mechanism which scavenges ROS successfully in plants under abiotic and biotic stresses (Schmidt et al., 1999; Liang et al., 2003; Asada, 2006). The activity of APX eliminates $\mathrm{H}_{2} \mathrm{O}_{2}$. Moreover, GR and DHAR both are principally accountable for providing substrate (reduced glutathione and ascorbate, respectively) for APX during scavenging of $\mathrm{H}_{2} \mathrm{O}_{2}$. The present study indicated that APX, DHAR, and GR were inhibited by excess $A s^{\mathrm{V}}$, and (Table 2) in accordance with the change of their activities in barley and bentgrass (Liang et al., 2003; Mittler et al., 2004; Foyer and Noctor, 2011). However, application of $\mathrm{Si}$ and $\mathrm{SiNp}$ enhanced their activities under $\mathrm{As}^{\mathrm{V}}$ stress demonstrating that rising AsA-GSH cycle components is one of key mechanisms to counteract $\mathrm{As}^{\mathrm{V}}$ stress in maize cultivar and hybrid as evidenced from data of oxidative stress (Table 2).

Furthermore, ascorbate and glutathione are recognized as the heart of the redox hub. Both antioxidants are abundant and stable with proper redox potentials that act together in several pathways and maintained in a commonly reduced condition (Foyer and Noctor, 2011). Mittler et al. (2004) demonstrated that both antioxidants are the element of an extremely complex and complicated plant antioxidative system. In the present study, oxidative stress caused by $\mathrm{As}^{\mathrm{V}}$ in maize seedlings and defense provided by both Si and SiNp may be linked with high levels of reduced ascorbate and glutathione, which are crucial nonenzymatic antioxidant having low molecular weight and act in coordinative way in AsA-GSH cycle for the elimination of $\mathrm{H}_{2} \mathrm{O}_{2}$ (Tables 3, 4). Oxidative stress induced by $\mathrm{As}^{\mathrm{V}}$ (25 and $50 \mu \mathrm{M})$ in maize cultivar and hybrid were further correlated with the redox status of ascorbate (AsA+DHA, AsA, and DHA) and glutathione (GSH+GSSG, GSH, and GSSG). It has been shown that ascorbate (AsA) plays an important role in scavenging ROS directly and indirectly (Foyer and Noctor, 2011; Singh et al., 2015a). Furthermore, the protective role of ascorbate (AsA) against oxidative stress has been demonstrated in Arabidopsis ascorbate-deficient ( $v t c 1$ ) mutant (Gao and Zhang,
2008). Another antioxidant, GSH, plays an important role in the synthesis of phytochelatins and in the removal of ROS (Kalinowska and Pawlik-Skowrónska, 2010) and also acts as a substrate in the detoxification of peroxidation products of lipids and proteins via the activity of glutathione-S-transferase ( $\mathrm{Li}$ et al., 2006; Gajewska and Skłodowska, 2010). Chen et al. (2010) have reported that exogenous application of GSH alleviates Cd-induced accumulation of $\mathrm{O}_{2}^{\bullet-}, \mathrm{H}_{2} \mathrm{O}_{2}$, and MDA in barley seedlings. The results of the present study showed that $\mathrm{As}^{\mathrm{V}}(25$ and $50 \mu \mathrm{M}$ ) severely alters the redox status of AsA and GSH (Tables 3, 4). Though AsA+DHA and GSH+GSSG increased by $\mathrm{As}^{\mathrm{V}}(25$ and $50 \mu \mathrm{M})$ exposures, however, DHA and GSSG were greatly increased, which result into a steep decline in AsA/DHA and GSH/GSSG ratios (Tables 3, 4). These results clearly reveal that $\mathrm{As}^{\mathrm{V}}(25$ and $50 \mu \mathrm{M})$ stress causes alteration in the redox status of the cell by interfering with AsA and GSH pools. However, addition of $\mathrm{Si}$ and $\mathrm{SiNp}$ restores the redox status of AsA and GSH pools as indicated by high ratios of AsA/DHA and GSH/GSSG and thus maintaining the redox buffering in maize cultivar and hybrid seedling (Tables 3,4). The results of enhanced AsA and GSH contents correspond with the enhanced activities of the AsA-GSH cycle enzymes i.e., GR and DHAR and thus, suggesting a role of $\mathrm{Si}$ and $\mathrm{SiNp}$ in triggering up-regulation of antioxidant defense system. Further, these results show that application of $\mathrm{Si}$ and $\mathrm{SiNp}$ under $\mathrm{As}^{\mathrm{V}}(25$ and $50 \mu \mathrm{M})$ stress reestablishes the redox status of the cell and thus mitigates $\mathrm{As}^{\mathrm{V}}$ toxicity.

\section{CONCLUSION}

The results showed that $\mathrm{As}^{\mathrm{V}}(25$ and $50 \mu \mathrm{M})$ caused decreases in growth of maize cultivar and hybrid seedlings by interfering with the photosynthesis, contents of photosynthetic pigments, SOD, APX, GR, DHAR, AsA, and GSH by enhancing oxidative damage through the accumulation of As. However, application of $\mathrm{Si}$ and $\mathrm{SiNp}$ protects maize cultivar and hybrid seedlings against $\mathrm{As}^{\mathrm{V}}$ by decreasing the accumulation of As and ROS, and enhancing levels of SOD, APX, GR, DHAR, AsA, and GSH, which re-establish the redox status of the cell and thus mitigate $\mathrm{As}^{V}$ toxicity. Comparing results of $\mathrm{Si}$ and $\mathrm{SiNp}$, it was observed that reductions in the accumulation of As and oxidative stress markers were higher under $\mathrm{SiNp}$ and $\mathrm{As}^{\mathrm{V}}$ combinations than $\mathrm{Si}$, which is due to greater availability of SiNp to seedlings than Si. Further, results show that levels of components of the AsA$\mathrm{GSH}$ cycle were higher in $\mathrm{SiNp}$ and $\mathrm{As}^{\mathrm{V}}$ combinations than $\mathrm{Si}$, which subsequently counterbalance ROS mediated damage to macromolecules more efficiently. Thus, the present study provides evidence that SiNp were more effective than $\mathrm{Si}$ in reducing $\mathrm{As}^{\mathrm{V}}$ stress in maize cultivar and hybrid. Further, the results of the present study may be interesting from agronomical point of view in crop breeding.

\section{AUTHOR CONTRIBUTIONS}

DKT, VPS, SMP, DKC, and NKD designed experiments. DKT and SS performed experiments. DKT, SS and VPS, analyzed data and wrote the manuscript. 


\section{ACKNOWLEDGMENTS}

DKT is thankful to the University Grants Commission, New Delhi for providing Dr. D. S. Kothari Post Doctoral Fellowship. The authors are thankful to Prof. A. C. Pandey

\section{REFERENCES}

Adrees, M., Ali, S., Rizwan, M., Zia-ur-Rehman, M., Ibrahim, M., Abbas, F., et al. (2015). Mechanisms of silicon-mediated alleviation of heavy metal toxicity in plants: a review. Ecotoxicol. Environ. Saf. 119, 186-197. doi: 10.1016/j.ecoenv.2015.05.011

Asada, K. (2006). Production and scavenging of reactive oxygen species in chloroplasts and their functions. J. Plant Physiol. 141, 391-396. doi: 10.1104/pp.106.082040

Brehe, J. E., and Burch, H. B. (1976). Enzymatic assay for glutathione. Anal. Biochem. 74, 189-197. doi: 10.1016/0003-2697(76)90323-7

Chen, F., Wang, F., Wu, F., Mao, W., Zhang, G., and Zhou, M. (2010). Modulation of exogenous glutathione in antioxidant defense system against $\mathrm{Cd}$ stress in the two barley genotypes differing in Cd tolerance. Plant Physiol. Biochem. 48, 663-672. doi: 10.1016/j.plaphy.2010.05.001

Currie, H. A., and Perry, C. C. (2007). Silica in plants: biological, biochemical and chemical studies. Ann. Bot. 100, 1383-1389. doi: 10.1093/aob/mcm247

Dickinson, M., and Scott, T. B. (2010). The application of zerovalent iron nanoparticles for the remediation of a uranium contaminated waste effluent. J. Hazard. Mater. 178, 171-179. doi: 10.1016/j.jhazmat.2010.01.060

Ding, W., Liu, W., Cooper, K. L., Qin, X. J., de Souza Bergo, P. L., Hudson, L. G., et al. (2009). Inhibition of poly(ADP-ribose) polymerase-1 by arsenite interferes with repair of oxidative DNA damage. J. Biol. Chem. 384, 6809-6817. doi: 10.1074/jbc.M805566200

Dubchak, S., Ogar, A., Mietelski, J. W., and Turnau, K. (2010). Influence of silver and titanium nanoparticles on arbuscular mycorrhiza colonization and accumulation of radio caesium in Helianthus annuus. Span. J. Agric. Res. 8, 103-108. doi: 10.5424/sjar/201008S1-1228

Elstner, E. F., and Heupel, A. (1976). Inhibition of nitrite formation from hydroxyl ammonium chloride: a simple assay for superoxide dismutase. Anal. Biochem. 70, 616-620. doi: 10.1016/0003-2697(76)90488-7

Epstein, E. (1999). Silicon. Annu. Rev. Plant Physiol. Plant Mol. Biol. 50, 641-664. doi: 10.1146/annurev.arplant.50.1.641

Feng, J. P., Shi, Q. H., and Wang, X. F. (2009). Effects of exogenous silicon on photosynthetic capacity and antioxidant enzyme activities in chloroplast of cucumber seedlings under excess manganese. Agric. Sci. China 8, 40-50. doi: 10.1016/S1671-2927(09)60007-9

Foyer, C. H., and Noctor, G. (2011). Ascorbate and glutathione: the heart of the redox hub. Plant Physiol. 155, 2-18. doi: 10.1104/pp.110.167569

Gajewska, E., and Skłodowska, M. (2010). Differential effect of equal copper, cadmium and nickel concentration on biochemical reactions in wheat seedlings. Ecotoxicol. Environ. Saf. 73, 996-1003. doi: 10.1016/j.ecoenv.2010.02.013

Gao, Q., and Zhang, L. (2008). Ultraviolet-B-induced oxidative stress and antioxidant defense system responses in ascorbate-deficient vtcl mutants of Arabidopsis thaliana. J. Plant Physiol. 165, 138-148. doi: 10.1016/j.jplph.2007.04.002

Giannopolitis, C. N., and Reis, S. K. (1977). Superoxide dismutase. I. Occurrence in higher plants. Plant Physiol. 59, 309-314. doi: 10.1104/pp.59.2.309

Gossett, D. R., Millhollon, E. P., and Cran, L. M. (1994). Antioxidant response to $\mathrm{NaCl}$ stress in salt-sensitive cultivars of cotton. Crop Sci. 34, 706-714. doi: 10.2135/cropsci1994.0011183X003400030020x

Heath, R. L., and Packer, L. (1968). Photoperoxidation in isolated chloroplasts I. Kinetics and stoichiometry of fatty acid peroxidation. Arch. Biochem. Biophys. 125, 189-198. doi: 10.1016/0003-9861(68)90654-1

Horiguchi, T., and Morita, S. (1987). Mechanism of manganese toxicity and tolerance of plants VI. Effect of silicon on alleviation of manganese toxicity of barley. J. Plant Nutr. 10, 2299-2310. doi: 10.1080/0190416870 9363778 and Dr. Prashant Kumar Singh, Nanotechnology Application Centre, University of Allahabad, Allahabad for providing SEM and XRD facilities to characterize SiNp. Authors are extended their gratitude to IIT, BHU for providing the EDX facility.

Kalinowska, R., and Pawlik-Skowrónska, B. (2010). Response of two terrestria green microalgae (Chlorophyta, Trebouxiophyceae) isolated from $\mathrm{Cu}$-rich and unpolluted soils to copper stress. Environ. Pollut. 158, 2778-2785. doi: 10.1016/j.envpol.2010.03.003

Kertulis-Tartar, G. M., Rathinasabapathi, B., and Ma, L. Q. (2009). Characterization of glutathione reductase and catalase in the fronds of two Pteris ferns upon arsenic exposure. Plant Physiol. Biochem. 47, 960-965. doi: 10.1016/j.plaphy.2009.05.009

Kidd, P. S., Llugany, M., Poschenrieder, C., Guns, B., and Barcel, J. (2001). The role of root exudates in aluminium resistance and silicon-induced amelioration of aluminium toxicity in three varieties of maize (Zea mays L.). J. Exp. Bot. 52, 1339-1352. doi: 10.1093/jexbot/52.359.1339

Kopittke, P. M., de Jonge, M. D., Menzies, N. W., Wang, P., Donner, E., McKenna B. A., et al. (2012). Examination of the distribution of arsenic in hydrated and fresh cowpea roots using two-and three-dimensional techniques. Plant Physiol. 159, 1149-1158. doi: 10.1104/pp.112.197277

Kuniak, E., and Skodowska, M. (2001). Ascorbate, glutathione and related enzymes in chloroplasts of tomato leaves infected by Botrytis cinera. Plant Sci. 169, 723-731. doi: 10.1016/S0168-9452(00)00457-X

Li, W., Chen, T., Huang, Z., Lei, M., and Liao, X. (2006). Effect of arsenic on chloroplast ultrastructure and calcium distribution in arsenic hyper accumulator Pteris vittata L. Chemosphere 62, 803-809. doi: 10.1016/j.chemosphere.2005.04.055

Liang, Y. C., Chen, Q., Liu, Q., Zhang, W. H., and Ding, R. X. (2003). Exogenous silicon $(\mathrm{Si})$ increases antioxidant enzyme activity and reduces lipid peroxidation in roots of salt-stressed barley (Hordeun vulgare L.). J. Plant Physiol. 160, 1157-1164. doi: 10.1078/0176-1617-01065

Lichtenthaler, H. K. (1987). Chlorophylls and carotenoids: pigments of photosynthetic biomembranes. Methods Enzymol. 148, 350-382. doi: 10.1016/0076-6879(87)48036-1

Liu, C., Li, F., Luo, C., Liu, X., Wang, S., Liu, T., et al. (2009). Foliar application of two silica sols reduced cadmium accumulation in rice grains. J. Hazard. Mater. 161, 1466-1472. doi: 10.1016/j.jhazmat.2008.04.116

McClintock, T. R., Chen, Y., Bundschuh, J., Oliver, J. T., Navoni, J., Olmos, V., et al. (2012). Arsenic exposure in Latin America: biomarkers, risk assessments and related health effects. Sci. Total Environ. 429, 76-91. doi: 10.1016/j.scitotenv.2011.08.051

Mittler, R., Vanderauwera, S., Gollery, M., and Van Breusegem, F. (2004). Reactive oxygen gene network of plants. Trends Plant Sci. 9, 490-498. doi: 10.1016/j.tplants.2004.08.009

Nair, R., Varghese, S. H., Nair, B. G., Maekawa, T., Yoshida, Y., and Kumar, D. S. (2010). Nanoparticulate material delivery to plants. Plant Sci. 179, 154-163. doi: 10.1016/j.plantsci.2010.04.012

Nakano, Y., and Asada, K. (1981). Hydrogen peroxide is scavenged by ascorbate specific peroxidase in spinach chloroplasts. Plant Cell Physiol. 22, 867-880.

Nordstrom, D. K. (2002). Public health. Worldwide occurrences of arsenic in ground water. Science 296, 2143-2145. doi: 10.1126/science.10 72375

Patel, K. S., Shrivas, K., Brandt, R., Jakubowski, N., Corns, W., and Hoffmann, P. (2005). Arsenic contamination in water, soil, sediment and rice of central India. Environ. Geochem. Health 27, 131-145. doi: 10.1007/s10653-0050120-9

Savant, N. K., Snyder, G. H., and Datnoff, L. E. (1997). Silicon management and sustainable rice production. Adv. Agron. 58, 151-199. doi: 10.1016/S00652113(08)60255-2

Schaedle, M., and Bassham, J. A. (1977). Chloroplast glutathione reductase. Plant Physiol. 59, 1011-1022. doi: 10.1104/pp.59.5.1011

Schmidt, R. E., Zhang, X., and Chalmers, D. R. (1999). Response of photosynthesis and superoxide dismutase to silica applied to creeping 
bentgrass grown under two fertility levels. J. Plant Nutr. 22, 1763-1773. doi: $10.1080 / 01904169909365752$

Shi, Q., Bao, Z., Zhu, Z., He, Y., Qian, Q., and Yu, J. (2005). Silicon-mediated alleviation of $\mathrm{Mn}$ toxicity in Cucumis sativus in relation to activities of superoxide dismutase and ascorbate peroxidase. Phytochemistry 66, 1551-1559. doi: 10.1016/j.phytochem.2005.05.006

Singh, R., Singh, S., Parihar, P., Singh, V. P., and Prasad, S. M. (2015). Arsenic contamination, consequences and remediation techniques: a review. Ecotoxicol. Environ. Saf. 112, 247-270. doi: 10.1016/j.ecoenv.2014. 10.009

Singh, V. P., Singh, S., Kumar, J., and Prasad, S. M. (2015a). Hydrogen sulfide alleviates toxic effects of arsenate in pea seedlings through upregulation of the ascorbate-glutathione cycle: possible involvement of nitric oxide. J. Plant Physiol. 181, 20-29. doi: 10.1016/j.jplph.2015. 03.015

Singh, V. P., Singh, S., Kumar, J., and Prasad, S. M. (2015b). Investigating the roles of ascorbate-glutathione cycle and thiol metabolism in arsenate tolerance in ridged Luffa seedlings. Protoplasma 252, 1217-1229. doi: 10.1007/s00709-0140753-6

Singh, V. P., Srivastava, P. K., and Prasad, S. M. (2013). Nitric oxide alleviates arsenic-induced toxic effects in ridged Luffa seedlings. Plant Physiol. Biochem. 71, 155-163. doi: 10.1016/j.plaphy.2013.07.003

Singh, V. P., Tripathi, D. K., Kumar, D., and Chauhan, D. K. (2011). Influence of exogenous silicon addition on aluminium tolerance in rice seedlings. Biol. Trace Elem. Res. 144, 1260-1274. doi: 10.1007/s12011-011-9118-6

Sooksaen, P., Suttiruengwong, S., Oniem, K., Ngamla-miad, K., and Atireklapwarodom, J. (2008). Fabrication of porous bioactive glassceramics via decomposition of natural fibres. J. Metals Mater. Miner. 18, 85-91.

Strasser, R. J., Srivastava, A., and Tsimilli-Michael, M. (2000). The Fluorescence Transient As a Tool to Characterize and Screen Photosynthetic Samples. Probing Photo- synthesis: Mechanisms, Regulation and Adaptation. New York, NY; London: Taylor and Francis.

Suriyaprabha, R., Karunakaran, G., Yuvakkumar, R., Rajendran, V., and Kannan, N. (2012). Silica nanoparticles for increased silica availability in maize (Zea mays L.) seeds under hydroponic conditions. Curr. Nanosci. 8, 902-908. doi: $10.2174 / 157341312803989033$
Tripathi, D. K., Singh, V. P., Kumar, D., and Chauhan, D. K. (2012). Impact of exogenous silicon addition on chromium uptake, growth, mineral elements, oxidative stress, antioxidant capacity, and leaf and root structures in rice seedlings exposed to hexavalent chromium. Acta Physiol. Plant. 34, 279-289. doi: 10.1007/s11738-011-0826-5

Tripathi, D. K., Singh, V. P., Prasad, S. M., Chauhan, D. K., Dubey, N. K., and Rai, A. K. (2015). Silicon-mediated alleviation of $\mathrm{Cr}(\mathrm{VI})$ toxicity in wheat seedlings as evidenced by chlorophyll florescence, laser induced breakdown spectroscopy and anatomical changes. Ecotoxicol. Environ. Saf. 113, 133-144. doi: 10.1016/j.ecoenv.2014.09.029

Velikova, V., Yordanov, I., and Edreva, A. (2000). Oxidative stress and some antioxidant system in acid rain-treated bean plants. Plant Sci. 151, 59-66. doi: 10.1016/S0168-9452(99)00197-1

Wang, M., Chen, L., Chen, S., and Ma, Y. (2012). Alleviation of cadmium-induced root growth inhibition in crop seedlings by nanoparticles. Ecotoxicol. Environ. Saf. 79, 48-54. doi: 10.1016/j.ecoenv.2011.11.044

Wang, S., Wang, F., and Gao, S. (2015). Foliar application with nano-silicon alleviates Cd toxicity in rice seedlings. Environ. Sci. Pollut. Res. 22, 2837-2845. doi: 10.1007/s11356-014-3525-0

Wilder, J. W., Venema, L. C., Rinzler, A. G., Smalley, R. E., and Dekker, C. (1998). Electronic structure of atomically resolved carbon nanotubes. Nature 391, 59-62. doi: 10.1038/34139

Zhao, F. J., Ma, J. F., Meharg, A. A., and McGrath, S. P. (2009). Arsenic uptake and metabolism in plants. New Phytol. 181, 777-794. doi: 10.1111/j.14698137.2008.02716.x

Conflict of Interest Statement: The authors declare that the research was conducted in the absence of any commercial or financial relationships that could be construed as a potential conflict of interest.

Copyright $\odot 2016$ Tripathi, Singh, Singh, Prasad, Chauhan and Dubey. This is an open-access article distributed under the terms of the Creative Commons Attribution License (CC BY). The use, distribution or reproduction in other forums is permitted, provided the original author(s) or licensor are credited and that the original publication in this journal is cited, in accordance with accepted academic practice. No use, distribution or reproduction is permitted which does not comply with these terms. 